\title{
Reviewing evidence of marine ecosystem change off South Africa
}

C L Moloney, S T Fennessy, M J Gibbons, A Roychoudhury, F A Shillington, B P von der Heyden \& K Watermeyer

\begin{abstract}
Recent changes have been observed in South African marine ecosystems. The main pressures on these ecosystems are fishing, climate change, pollution, ocean acidification and mining. The best long-term datasets are for trends in fishing pressures but there are many gaps, especially for non-commercial species. Fishing pressures have varied over time, depending on the species being caught. Little information exists for trends in other anthropogenic pressures. Field observations of environmental variables are limited in time and space. Remotely sensed satellite data have improved spatial and temporal coverage but the time-series are still too short to distinguish long-term trends from interannual and decadal variability. There are indications of recent cooling on the West and South coasts and warming on the East Coast over a period of 20-30 years. Oxygen concentrations on the West Coast have decreased over this period. Observed changes in offshore marine communities include southward and eastward changes in species distributions, changes in abundance of species, and probable alterations in foodweb dynamics. Causes of observed changes are difficult to attribute. Full understanding of marine ecosystem change requires ongoing and effective data collection, management and archiving, and coordination in carrying out ecosystem research.
\end{abstract}

\section{Introduction}

Human activities are changing marine environments at global (Checkley et al. 2009a, Barange et al. 2010) and local (Hutchings et al. 2012) scales. Pressures on the oceans are linked to climate change (through changes in ocean temperature, ocean circulation, stratification and nutrient availability), ocean acidification, marine pollution, marine habitat alteration and destruction, coastal eutrophication, the spread of invasive species and fishing. These large-scale impacts occur concurrently and their effects can be synergistic, increasing the vulnerability of natural systems and at the same time making it difficult to predict how the ecosystems might respond (Link et al. 2010). Predictions of future change typically are based on results of models that combine best understanding of ecological processes with observations. Although global models predict likely consequences of change (e.g. Cheung et al. 2009), refining these predictions for specific regions is problematic because of difficulties in downscaling to local scales. Similarly, observed and perceived changes are difficult to identify and to attribute to particular causes because of the complexities of the processes involved (Fulton et al. 2003, Jarre et al. 2006), the variety of scales at which 
they operate (Field and Shillington 2006) and the general paucity of ocean observations in relation to what is needed (Moloney and Shillington 2007).

The marine ecosystems off South Africa are naturally variable on interannual and decadal time-scales. This variability makes it difficult to separate long-term trends from large-amplitude, short-term variability (Hutchings et al. 2009). At the same time, the large variability results in strong signals in datasets and has promoted a good understanding of the scales of variability and some of their proximal causes. However, unequivocal, unidirectional change cannot be identified from short timeseries and changes cannot be detected without having an historical baseline against which to compare modern observations. This paper aims to synthesise what is currently known about global change and its impacts on continental shelf ecosystems off South Africa, including studies from the Thukela Bank, the KwaZulu-Natal Bight, the Benguela upwelling region and the Agulhas Bank. It also draws on the results of studies targeting demersal and reef-fish communities. The paper highlights some predictions of the impacts of change and the data that currently exist to test these predictions and constrain models, and it identifies gaps in knowledge as well as advises on priorities for future research.

\section{Pressures on South African marine ecosystems and their likely impacts Climate change as a pressure on the ecosystem}

There is widespread acceptance that contemporary climate change (Figure 1) is an important and increasing factor influencing marine ecosystems. General pressures in the ocean resulting from climate change include warming of the surface ocean, especially at the poles (IPCC 2007), increased wind stress (Young et al. 2011), more extensive low-oxygen zones (Diaz and Rosenberg 2008), increased surface stratification (Sarmiento et al. 1998) and changes in nutrient distributions (Deutsch et al. 2005).

\section{Impacts of climate change}

There is less temperature variability in the ocean than on land (Sunday et al. 2011), so marine ectotherms in a warming ocean should change their ranges rather than expand them. These range shifts are predicted to occur towards the poles and to increased depths (Perry et al. 2005, Dulvy et al. 2008), and changes in distributions have been observed for individual species (Perry et al. 2005) and also entire communities (Beaugrand 2009). Changes in phenology have also been observed, with the onset of spring (a strong environmental signal in many marine ecosystems) generally occurring earlier each year (Parmesan 2007). Increased sea temperatures should enhance overall marine foodweb productivity at high latitudes, but reduced productivity is predicted in the tropics (Brander 2007). These changes should affect fisheries productivity (Brown et al. 2010) and also potentially cause dramatic changes in foodwebs and links to higher trophic levels (Moloney et al. 2010). There is also some evidence that climate warming could decrease body size (Sheridan and Bickford 2011), with implications for system productivity and biodiversity.

Despite these general predictions and some observations from different regions, understanding the impacts of climate change on the oceans generally lags that of 
terrestrial ecosystems (Cheung et al. 2009). At a South African workshop held in 2000, most of the expert opinion summarised by van Jaarsveld and Chown (2001) focused on impacts on terrestrial and freshwater ecosystems. Five years later, Clark (2006) reviewed the main effects of climate change on South Africa's marine environment and fisheries, presenting some generic predicted outcomes based on research and observations from elsewhere in the world. These predictions included changes in sea temperatures, wind fields, $\mathrm{CO}_{2}$ concentrations, rainfall (and runoff) and ultraviolet $\mathrm{B}$ radiation, but they were non-specific because there were few data with which to test their occurrences off South Africa. The situation has not changed much to date.

\section{Fishing as a pressure on the ecosystem}

Fishing is an activity with a long history, and fishing pressures have increased over time as human population numbers have increased, expanding from coastal and nearshore areas to the entire oceanic realm. Overfishing has been common in recent decades, reducing biodiversity and altering marine ecosystems (Worm et al. 2009). Off South Africa, commercial fishing has a history of more than 400 years, starting with the harvesting of seals in the early 1600s (Shaughnessy 1984), collection of penguin eggs from the mid-16oos (Randall 1995) and development of the whaling industry in the early 1700s (Best et al. 1997). Most of these early commercial activities targeting marine mammals and seabirds have now ceased, and the modern focus is on exploitation of species of fish, crustaceans and molluscs.

Demersal trawling started gradually from 1900 and expanded rapidly from the 1950 s (Cochrane et al. 1997). Stability was achieved after 1977 (Figure 2) when South Africa declared a 200-mile exclusive economic zone (Cochrane et al. 1997). The fishery initially targeted Agulhas sole Austroglossus pectoralis (Brown 1997) and then Cape hakes, Merluccius paradoxus and $M$. capensis, but many other piscivorous fish species were taken as bycatch. The bulk of present-day demersal harvesting is concentrated around the Western Cape. Other important but low-volume bottom fisheries include those for rock lobsters in the nearshore environment off the West Coast (for Jasus lalandii) and on the South Coast (for Palinurus gilchristi) (Mead et al. 2013).

South Africa's largest fishery in terms of volume landed is the pelagic purse-seine fishery on the West and South coasts (Figure 2), primarily consisting of sardine Sardinops sagax and anchovy Engraulis encrasicolus. These small pelagic fish species were first caught commercially in the 1940s (Butterworth 1983), with catches increasing rapidly in the 1960s, necessitating the introduction of various management measures (Cochrane et al. 1997). The small pelagic fishery is characterised by large interannual variability in the catches and dramatic changes in relative species abundance (Figure 2).

The linefishery has been in existence since the late 16oos (Penney et al. 1997) and is much more diffuse than the major pelagic and demersal trawl fisheries, with catches landed by small-scale commercial fishers on small boats, as well as by recreational boat- and shore-anglers. It is a multispecies fishery, with many of the species also caught as bycatch in the demersal trawl fishery (Attwood et al. 2011). 


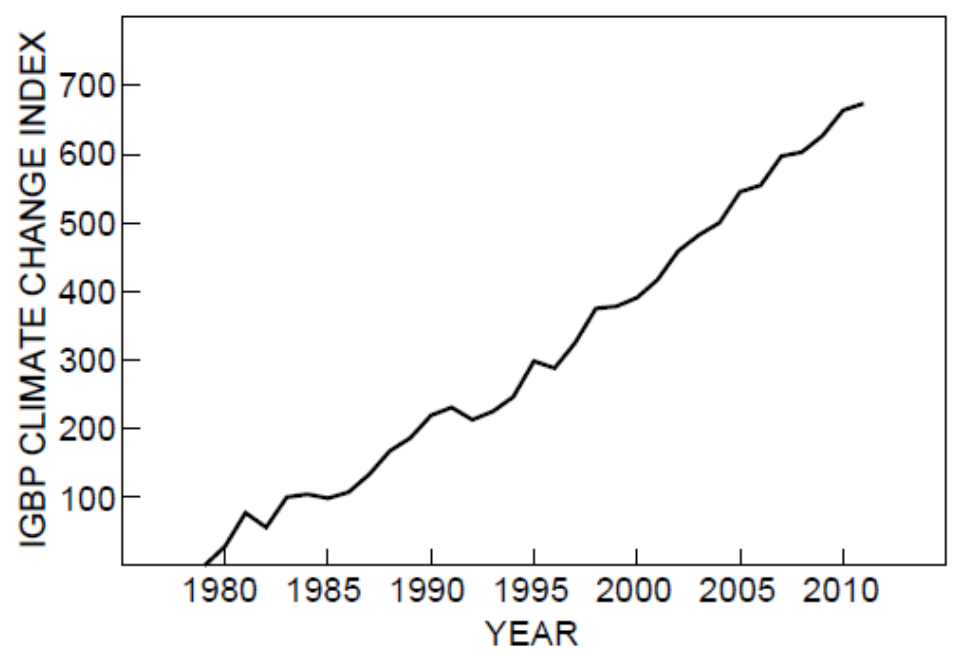

Figure 1: The International Geosphere-Biosphere Programme (IGBP) climate change index (IGBP 2012), based on four key indicators of global change: atmospheric carbon dioxide concentrations, global surface temperature, global mean sea level and the Arctic sea-ice minimum areal extent (after IGBP 2012)

The linefishery extends along the whole South African coastline, although there are centres of activity at Saldanha Bay, Struis Bay, Port Elizabeth and Richards Bay. Offshore reefs are readily accessible to fishers, and many of the target species are endemic, long-lived, slow-growing, resident, sex-changing predators, which have been heavily overexploited (Mann 2000; Figure 2). The declaration of a crisis in the linefishery in 2000 (Branch and Clark 2006) was followed in 2002 by substantial reductions in commercial permits and reduced recreational bag limits (Griffiths et al. 2004).

\section{Impacts of fishing}

The general impacts of fishing worldwide are well known. Fishing reduces the abundance of selected species and truncates the age structures of their populations, increasing their dependence on annual recruitment events (Perry et al. 2010) and reducing their ability to buffer environmental fluctuations (Planque et al. 2010). Fish adults and larvae show greater population variability in exploited than unexploited populations (Hsieh et al. 2006, 2008), but this effect has not been observed off South Africa. Fishing also affects sex ratios, with species exhibiting protogynous hermaphroditism being most impacted (Garratt et al. 1993). Populations of top predators have been found to be vulnerable to incidental mortality associated with fishing gear (Watkins et al. 2008, Petersen et al. 2009, Meÿer et al. 2011) and to local prey depletion through fishing (Pichegru et al. 2010). Fishing gear can also impact substrata, having a direct effect on invertebrate and vertebrate communities (Atkinson et al. 2011a). Fishing can restructure foodwebs (Roux and Shannon 2004) by removing predator controls and depleting forage fish species (Shannon et al. 2000). 
(a)
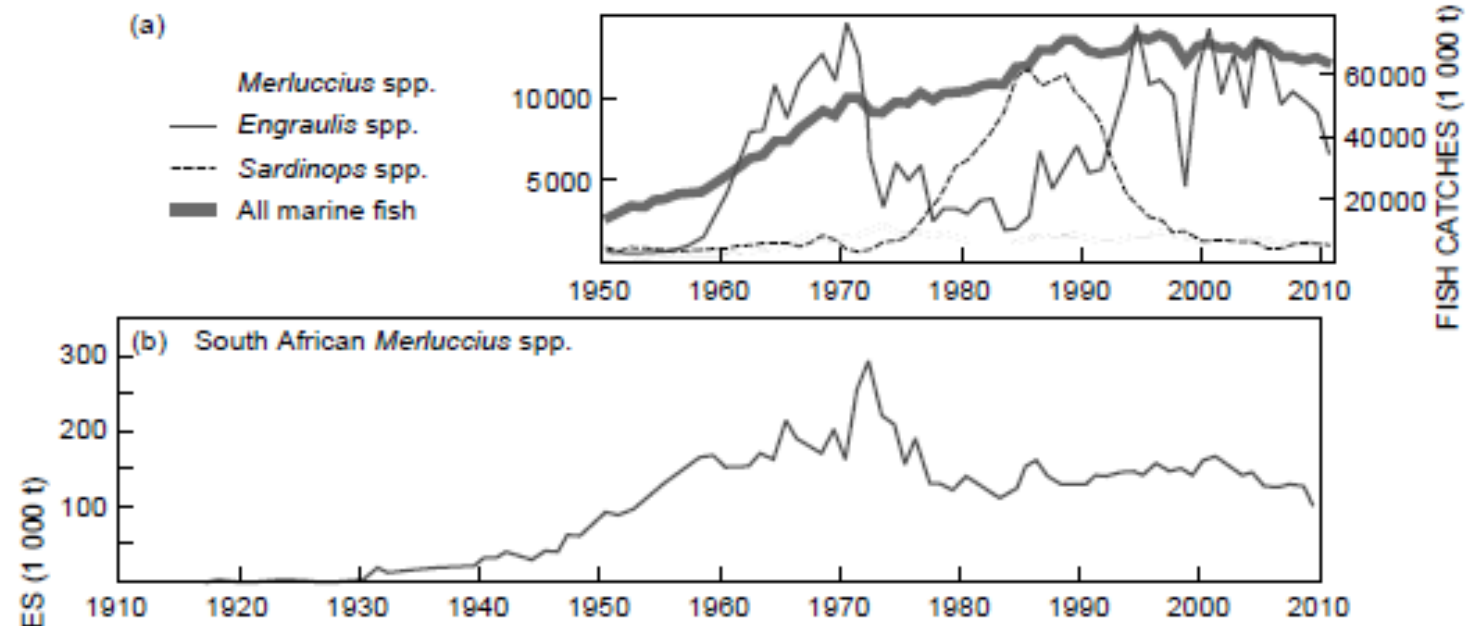

(c)
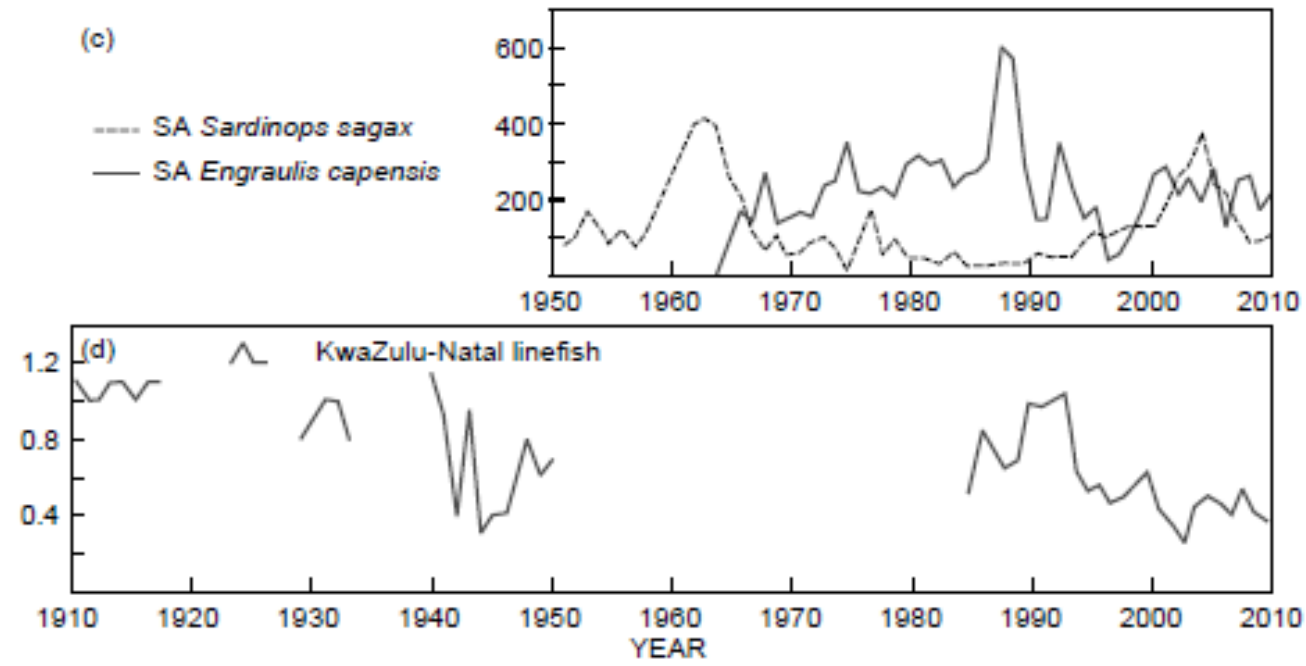

Figure 2: Trends in fish catches over time for (a) global catches of all marine fish (right axis), hakes and small pelagics (left axis) since 1950 (source: FAO, http://www.fao.org/figis/servlet/SQServlet?file=/usr/local/tomcat/Fl/5.5.23/figis/webapps/figis/temp/hqp_7150_xml\&outtype=htm/ [accessed 19 June 2012]). (b) South African landings of Merluccius spp. (source: 1917-1995 after Cochrane et al. 1997; 1996-2009 - George Warman Publications 2011), (c) South African landings of Sardinops sagax and Engraulis encrasicolus (source: 1950-1995 after Cochrane et al. 1997; 1996-2009 - George Warman Publications 2011), (d) landings of linefish in KwaZulu-Natal (source: 1910-1985 after Penney et al. 1999; 1996-2010 from STATBASE http//vmstatbase-dev.mpl.ird.fr/statbase_3/ [accessed 19 June 2012]). All catches are in 1000 t

In South Africa, investigation of changes caused by fishing pressure initially focused on the target species to try and optimise catches (see management measures reviewed in Cochrane et al. 1997). Later, attention was increasingly focused on the impacts on nontarget species through, for example, studies of bycatch (e.g. Fennessy 1994, Walmsley et al. 2007), catch composition from research surveys (e.g. Wallace et al. 1984, Japp et al. 1994, Yemane et al. 2005), predator-prey interactions (e.g. Crawford and Dyer 1995, Punt and Butterworth 1995) and environmental effects (van der Lingen et al. 2006a, Watermeyer et al. 2008). Near Tsitsikamma, fishing on a temperate reef community was found to affect the size and abundance of roman Chrysoblephus laticeps (Götz et al. 2009a), the dominant fish species in catches, allowing their competitors to increase and also affecting benthic communities (Götz et al. 2009b). Small marine protected areas have been found to benefit resident fish populations like roman that are heavily exploited (Kerwath et al. 2008), whereas seasonal or spatial closures can be used for wide-ranging or migratory species (Grantham et al. 2008). 


\section{Marine pollution as a pressure on the ecosystem}

Pollution problems can be related to increasing human populations and increased urbanisation and industrialisation (Ukwe and Ibe 2010). Ocean pollution results from both point sources and diffuse sources. Point sources include harbours, sea-outfalls, stormwater drains, canals and rivers. Diffuse sources include the land-sea interface (coastal litter), ships at sea and atmospheric deposition (Ryan et al. 2009). Most sources have localised impacts in the nearshore zone, and contaminants are likely to be rapidly diluted by strong currents and mixing and so have limited impacts offshore (Marshall and Rajkumar 2003), but this needs to be confirmed.

Oil pollution is caused by accidental spills and deliberate discharges, with the latter generally believed to be most common (Pavlakis et al. 2001). The frequency of oil spills might be expected to have increased because of increased shipping traffic (Wolfaardt et al. 2009), but there are no readily accessible time-series data on historic or current oil contamination off South Africa and so it is not possible to identify trends. Three major accidental oil spills associated with the break-up of ships were documented off the SouthWest Coast in the past 30 years (Wolfaardt et al. 2009) and there were more seabird oiling events (from identified and unknown sources) in the 2000s (10) than in earlier decades (2-7) (http://www.sanccob.co.za/? $\mathrm{m}=2 \& \mathrm{~s}=3$, accessed 30 June 2012), but these results are not statistically significant $\left(x^{2}=5.67, \mathrm{df}=2, p=0.13\right)$.

Measurements of deleterious trace elements and compounds released into the marine environment by industrial and mining activities, and organic-rich effluents associated with sewage outfalls and agricultural effluent, have been mostly confined to point sources along the KwaZulu-Natal coastline or near urban centres and in harbours (Griffiths et al. 2010). Elevated levels of iron and titanium have been noted around the HuntsmanTioxide pipe off Amanzimtoti (Gregory et al. 2003) and trace metals in sediments off the Thukela Bank have exceeded acceptable toxicity threshold levels, with the main sources ascribed to terrestrially derived clays (Carter 2006). Tributyltin (TBT) contamination (mainly from antifouling paints) has been observed in harbours at Durban and Richards Bay and in Knysna Lagoon (Marshall and Rajkumar 2003). An accumulation of toxic compounds has been reported in the mussel Choromytilus meridionalis in the southern Benguela (Krock et al. 2009), originating from algal species under the influence of trace metals (Rhodes et al. 2006).

Persistent organic pollutants (POPs) are produced mainly through industry and agriculture, the latter via the use of pesticides. POPs reach the oceans via point sources at the coast and atmospheric deposition. They can be transported large distances, frequently on the surfaces of plastic particles (Mato et al. 2001), especially microplastics $(<5 \mathrm{~mm}$ ) (Andrady 2011). Global monitoring of POPs is being done by the International Pellet Watch (http://www.pelletwatch. org/), which uses volunteers to collect plastic resin pellets from beaches and produces global maps showing concentrations at different geographical locations (Ogata et al. 2009). Current high values (Table 1) of hexachlorocyclohexanes (HCHs) from South Africa compared to other regions are believed to indicate their ongoing use in pesticides in the agricultural industry (Ogata et al. 2009). There are indications that the trends in POP concentrations off South Africa since the mid-1980s are decreasing or constant for concentrations of $\mathrm{HCHs}$, 
polychlorinated biphenyls (PCBs) and p,p'-dichlorodiphenyltrichloroethane (DDT) and its metabolites (Ryan et al. 2012).

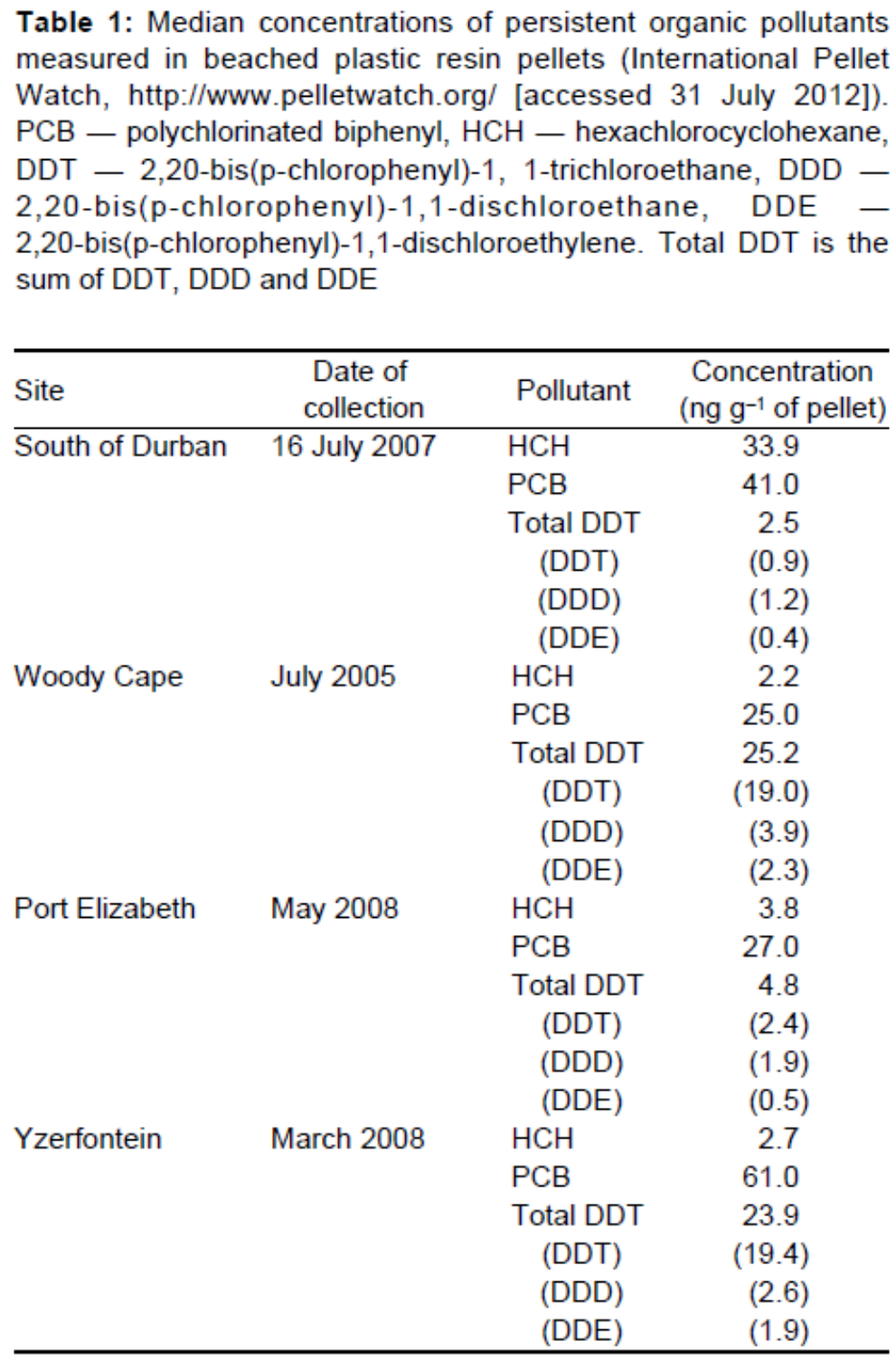

Marine plastic pollution is a global problem, with most information coming from surveys of plastics stranded on beaches (Coe and Rogers 1997), which are assumed to be representative of at sea pollution. Baseline data exist for South Africa from the 1980 s (Ryan and Moloney 1990), with ongoing monitoring at five-year intervals. There has been a steady increase in plastic litter items on South African beaches (Figure 3), notwithstanding a concurrent increase in extensive and expensive beach-cleaning efforts by local municipalities and regional authorities (Ryan and Swanepoel 1996). However, there is little information on trends in microplastics and the extent to which these small particles might be entering marine foodwebs (Andrady 2011).

\section{Impacts of marine pollution}

Impacts of pollution can be acute or chronic. Oil spills typically represent acute impacts, often measured by their effects on seabirds. Species most severely affected are the African penguin Spheniscus demersus, Cape gannet Morus capensis and several species of gulls and cormorants. However, impacts of oiling extend beyond direct, immediate mortality 
and include chronic effects through reduced breeding productivity and life expectancy of de-oiled birds (Adams 1994, Altwegg et al. 2008, Wolfaardt et al. 2008a, 2008b). A variety of toxic substances in the marine environment are absorbed and ingested by living organisms, some of them bio-accumulating in the foodwebs (Cockcroft et al. 1989). Elevated concentrations of trace metals can increase algal bloom toxicity, affecting shellfish aquaculture (Rhodes et al. 2006). Marine plastic debris has been shown to entangle sealife, be ingested by many organisms, act as a substratum for other pollutants, help disperse invasive species, reduce aesthetics and smother benthic habitats (Gregory 2009).

\section{Hypoxia as a pressure on the ecosystem}

Ocean hypoxia occurs when dissolved oxygen concentrations in seawater range between 0.5 and $2 \mathrm{ml} \mathrm{l}-1$ and anoxia occurs at $<0.5 \mathrm{ml} \mathrm{l-1}$ [O2]. Naturally occurring oxygen minimum zones are found in eastern boundary upwelling ecosystems, and it has been hypothesised that global warming will also lead to an expansion of these zones (Stramma et al. 2010). In the southern Benguela region, hypoxic conditions develop north of the Cape Columbine upwelling cell (Penven et al. 2000), with remineralisation of high surface productivity forming low-oxygen waters at depth in a stratified system. Advection of this water mass causes variability in hypoxia in the rest of the region (Monteiro and van der Plas 2006). Effective wind-stress (which drives upwelling) and insolation (which drives stratification) cause seasonal and interannual variability in coastal hypoxic events. Episodic events can proceed to anoxia and are associated with harmful algal blooms and widespread mortality of marine species (Cockcroft et al. 2000).

\section{Impacts of low-oxygen water}

The effects of low-oxygen conditions are most notable when rock lobster Jasus lalandii walkouts occur (Cockcroft et al. 2000), although other impacts are possible, such as mortality of other benthic organisms (Zhang et al. 2010), mass mortalities of pelagic fish (Diaz and Rosenberg 2008) and detrimental effects on fish spawning and egg development (Ekau and Verheye 2005). Low-oxygen conditions can also affect inorganic elemental cycles, particularly the redox active metals iron and manganese, as well as their associated surface adsorbed species (i.e. $\mathrm{PO}_{4}, \mathrm{NH}_{3}$ ). Once stratification conditions have broken down, outgas- sing of greenhouse-active species $\left(\mathrm{CO}_{2}, \mathrm{~N}_{2} \mathrm{O}\right.$ and $\left.\mathrm{CH}_{4}\right)$ is also known to occur (Weeks et al. 2002, Santana-Casiana et al. 2009). The meteorological variables influencing the formation of low-oxygen water are sensitive to climate-related change and should be monitored in the future. 


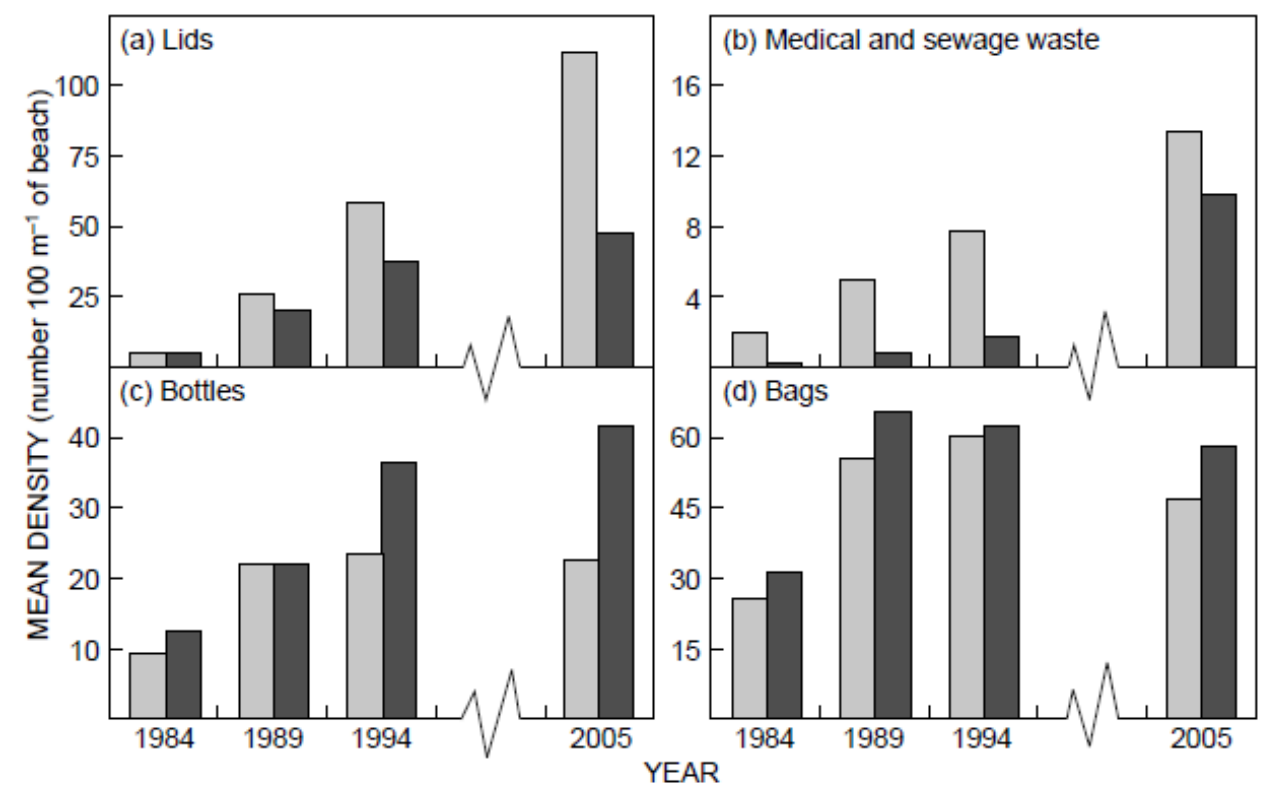

Figure 3: Trends in the abundance of selected plastic litter items at 50 South African beaches sampled in 1984, 1989, 1994 and 2005. Pale shading represents all beaches; dark bars = rural beaches with no municipal cleaning programmes (PG Ryan and CL Moloney, University of Cape Town, unpublished data)

\section{Ocean acidification as a pressure on the ecosystem}

Ocean acidification is an environmental issue that has scarcely been addressed in southern African waters. Ocean $\mathrm{pH}$ can decrease as a result of localised inputs to nearcoastal environments of acidic compounds, such as nitric and sulphuric acid (Doney et al. 2007), and nutrient loading controls on carbonate chemistry (Borges and Gypens 2010), but these effects are largely confined to urban coastal settings. The main cause of ocean acidification is increasing concentrations in the ocean of dissolved $\mathrm{CO} 2$, which reacts with seawater to form increased concentrations of bicarbonate (HCO-) and hydrogen $(\mathrm{H}+)$ ions and decreased concentrations of carbonate ions ( $\mathrm{CO}_{2}-$ ). Cold water at high pressure has the greatest capacity to take up excess $\mathrm{CO}_{2}$ and ocean acidification is most noticeable at high latitudes and at depth (Orr et al. 2005).

Some ocean areas are naturally more acidic than others because excess $\mathrm{CO} 2$ is introduced to their surface waters through remineralisation of organic matter at depth followed by upwelling (Feely et al. 2008). This process is important in eastern boundary upwelling systems, such as off the west coast of South Africa, resulting in seawater with naturally low $\mathrm{pH}$ values. Gruber et al. (2012) showed that these ecosystems might be particularly vulnerable to increasing anthropogenic $\mathrm{CO} 2$ concentrations. The authors used a number of model scenarios of the California Current system and predicted that the nearshore region might become undersaturated in aragonite, one of the mineral forms of calcium carbonate, within the next two to three decades.

\section{Impacts of ocean acidification}

Calcareous organisms are at particular risk of dissolution in more acidic conditions as calcite and aragonite saturation states decrease. However, the ultimate effects can be more complex, and localised effects of physiology (Checkley et al. 2009b) and cellular microclimate (Flynn et al. 2012) can be more important than bulk seawater $\mathrm{CO} 2$ concentrations and $\mathrm{pH}$ in determining outcomes. In the marine environment off South 
Africa there is little information available on historical or current $\mathrm{pH}$ values, although there have been some recent studies examining the impacts of ocean acidification on coral reefs (Mead et al. 2013). Organisms most at risk from acidification include planktonic groups like coccolithophores, pteropod molluscs and foraminiferans (Fabry et al. 2008), benthic molluscs (Gazeau et al. 2007) and crustaceans (Spicer et al. 2007). The benthic groups contain commercially important species for fisheries and aquaculture.

\section{Mining, exploration and extraction as pressures on the marine ecosystem}

The exploration for non-renewable resources in South Africa and their extraction can threaten regional biodiversity, with perceived threats decreasing from inshore to offshore and from west to east (Lombard et al. 2004). The most important non-renewable resources are hydrocarbons (oil and gas) and various minerals (principally diamonds), most of which are located on the west and south-west coasts of South Africa. To date, most marine mining operations have been conducted at water depths $<140 \mathrm{~m}$, although as technology develops and resource values increase, it is likely that reserves and deposits at greater depths will become viable. For example, off Namibia there are now plans to extract phosphates from sediments at depths in excess of $180 \mathrm{~m}$ (Midgley 2012). The drivers of the exploitation of marine non-renewable resources are purely economic and largely dictated by forces outside of the region.

\section{Impacts of non-renewable resource exploitation}

There is almost no published information on the impacts of non-renewable resource exploitation around South Africa, although a number of reports have been published in the grey literature. Direct impacts of resource extraction include changes to seabed topography and sediment particle structure. These changes in turn can affect bottom currents and sediment transport pathways, as well as biological communities. Indirect effects can also occur at the coast in terms of beach drawdown and changes to wave conditions and tidal currents. In many cases, sediments are released into the water column and these sediment plumes affect turbidity. Ultimately, the suspended sediments settle out, altering the nature of the seabed habitats and smothering benthic organisms, although these impacts depend largely on the type of mining operation, the sediment type and local hydrodynamics. The extraction of minerals off the west coast of southern Africa might also be accompanied by the release of toxic hydrogen sulphide (H2S) and methane, and the resuspension of organic-rich fines can lead to localised hypoxia, as well as (potentially) the release of toxic compounds that have been sequestrated over time in the sediments (Ryan et al. 2012). There also may be cumulative effects caused by extraction from adjacent operations, in time and space, by the same or different license holders.

Regionally, it is clear from published work off southern Namibia that diamond mining has an effect on the composition of the sediments, and the natural 'fining-upward' sequence of deposits is completely and 'irrevocably' altered (Rogers and Li 2002). This leads to an increase in the textural heterogeneity of the substratum, and must inevitably lead to an altered benthic fauna. Information is entirely missing on natural levels of variability in the physical and biological benthic environment. As a consequence, it is impossible at this stage to contextualise environmental changes induced by the extraction of non-renewable resources in South African marine ecosystems, although the area of the seabed that is currently being exploited is relatively small.

\section{https://repository.uwc.ac.za}




\section{Observed changes to South African marine ecosystems Observed changes in the physical environment off South Africa}

Using satellite-derived sea surface temperature data (SST), Roy et al. (2007) and Rouault et al. (2010) found cooling trends nearshore off the west and south coasts of South Africa, which they attributed to an increase in upwelling-favourable winds. This contrasts with the results of Demarcq (2009), who used Pathfinder version 5 data products and found a weak warming trend of $0.1^{\circ} \mathrm{C}$ decade- 1 for the southern Benguela over the period 19982007. However, Dufois et al. (2012) reported a warm bias in the Pathfinder data for versions before version 5.2, and suggested this bias is the cause of the discrepancy. Roy et al. (2007) found that the inner shelf east of Cape Agulhas became colder by about $0.5{ }^{\circ} \mathrm{C}$ in 1996; this cooling has persisted. The shift was linked to signals in atmospheric surface pressure and zonal wind data, indicating the main driver of the cooling was an increase in coastal upwelling east of Cape Agulhas.

Rouault et al. (2010) also analysed monthly SSTs (from 1985 to 2009). They showed a cooling trend nearshore off the West (January-August) and South (May-August) coasts, and a warming trend offshore in the Agulhas Current (all year) and off KwaZulu-Natal (in summer only). The cooling was attributed to an increase in upwelling-favourable winds. The warming was attributed to an intensification of the Agulhas Current, caused by changes in winds. Both sets of results are consistent with the hypothesis that eastern boundary ecosystems will experience an increase in upwelling-favourable winds, because of intensified atmospheric pressure gradients in coastal areas (Bakun and Weeks 2008). Demarcq (2009) used monthly wind data and noted an increase of $0.36 \mathrm{~m} \mathrm{~s}-1$ decade-1 in the strength of the equatorward component of the winds in the southern Benguela from 2000 to 2007. In general, observed global trends (derived from a 23-year time-series from satellite altimeter measurements) indicate increased wind speed and wave height in the oceans (Young et al. 2011), with a rate of increase that is greater for extreme events. The remotely sensed SST and wind datasets off South Africa span less than three decades. Observed variability in ocean conditions are known to occur on many scales (Hermes et al. 2007), some of which have decadal periods, and it is important to continue building on these time-series and analyses to confirm long-term trends.

\section{Observed changes in ocean chemistry off South Africa}

Datasets that can be used to estimate average or baseline dissolved O2 concentrations extend from 1958 for the southern Benguela (Monteiro and van der Plas 2006). There has been a significant decreasing trend in dissolved oxygen at St Helena Bay on the West Coast (Hutchings et al. 2009, 2012), at a rate of approximately $20 \mu \mathrm{l}-1 \mathrm{y}-1$ (Figure 4). Information pre-dating these dissolved $\mathrm{O}_{2}$ datasets is in the form of historical documentation of severe anoxic events, which have happened intermittently, the earliest dating back to 1869 (Pitcher and Calder 2000). It is not possible to assess longer-term oxygen changes in the region caused by anthropogenic activity, particularly since the onset of industrialisation. Models of hypoxia and upwelling are generally site-specific and cannot be adapted easily to other areas with similar conditions (Peña et al. 2010), implying that any given 'baseline' value is only valid for the site for which the model was developed. 


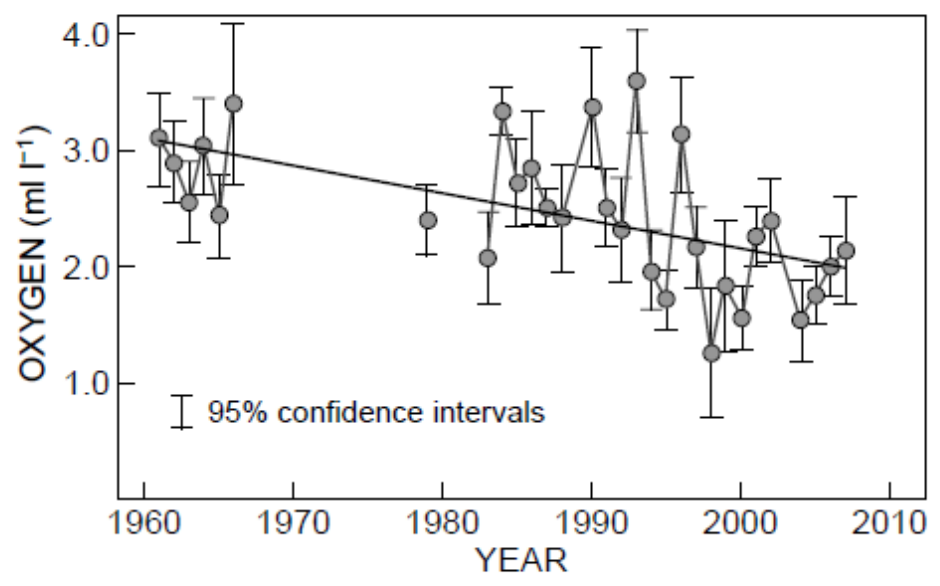

Figure 4: Changes in mean oxygen concentrations $\left(\mathrm{ml} \mathrm{l}^{-1}\right)$ in the sub-thermocline layer in St Helena Bay $\left(32^{\circ} \mathrm{S}\right), 1957-2007$, indicating a significant decrease $(p<0.01)$ since 1960 in oxygen concentrations of approximately $1 \mathrm{ml} \mathrm{l}^{-1}(35 \%)$ over a period of 50 years (after Hutchings et al. 2009)

On the East Coast, upwelling has been observed inshore of the Agulhas Current at three different sites: Cape St Lucia (Lutjeharms et al. 2000a), Port Alfred (Lutjeharms et al. 200ob) and Jeffreys Bay (Schumann et al. 1982). Although dissolved oxygen measurements have been taken (Lutjeharms et al. 2010), there have been no reports of ocean anoxia or hypoxia in these areas. However, the formation of intermittent and localised low-oxygen events in these areas cannot be excluded as the temporal scale for sampling has been irregular and future work could identify East Coast upwelling sites where low-oxygen conditions develop.

Ship-based studies off the central KwaZulu-Natal shelf in 2009 and 2010 recorded an area of low-oxygen water in the vicinity of the Thukela River (Oceanographic Research Institute, Durban, unpublished data). The origins, extent and temporal nature of this lowoxygen event have yet to be determined. Persistent upwelling is known from the nearby KwaZulu-Natal Bight inshore of the Agulhas Current (Lutjeharms et al. 1989, Meyer et al. 2002), boosting nutrient levels in an otherwise oligotrophic system (Hutchings et al. 2010). However, this is unlikely to cause anoxic or hypoxic conditions. Rather, lowoxygen waters are thought to be a consequence of the substantial outflow from nearby rivers of organic matter of terrestrial origin, which subsequently decomposes (Oceanographic Research Institute, Durban, unpublished data).

\section{Observed changes in marine organisms and communities off South Africa}

General responses in marine ecosystems to recent environmental change include changes in distribution and local abundance of species, changes in phenology, changes in community composition, changes in dominant foodweb pathways and ecosystem dynamics, and changes in morphology and behaviour (Parmesan 2006).

\section{Changes in distribution and local abundance}

There are some useful, long-term datasets from South Africa that allow assessments of long-term trends (Table 2), but in many cases the time-series are too localised, too short or are interrupted. In general, trends in abundance at low trophic levels are typically 
explained by changes in the physical and chemical environment, those at high trophic levels by fishing (Fréon et al. 2005) and at mid-trophic levels by a combination of the two (Table 2). Pollution, ocean acidification and mining are rarely invoked as explanations.

An increasing trend in measured surface chlorophyll during the 1990 os has been documented for the West Coast, based on data from the St Helena Bay region (Verheye 2000), but Hutchings et al. (2009) found little overall trend in chlorophyll measurements from 2000 to 2008 in the same region. For the southern Benguela ecosystem as a whole, the phytoplankton variability derived from SeaWiFS ocean colour data and modelled primary production based on depth-integrated chlorophyll $a$ distributions showed no trend over the period 1997 to the early 2000s (Demarcq et al. 2007). However, there was an average decrease of $0.4 \mathrm{mg} \mathrm{Chl} \mathrm{m-3}$ decade -1 over the continental shelf when the time-series was longer, from 1998 to 2007 (Demarcq 2009), with most of the decrease south of Cape Columbine. Zooplankton vary both spatially and temporally around the South African coastline, with inshore diversity being generally higher and biomass lower along the East Coast than the West Coast (Verheye et al. 1994). Seasonal zooplankton maxima appear in spring/summer, related to indices of wind-driven upwelling (Richardson et al. 2003, Hutchings et al. 2006), although winter copepod production also contributes significantly to annual production (Huggett et al. 2009). A long-term increase in the abundance of zooplankton in St Helena Bay on the West Coast from 1951-1996 (Verheye et al. 1998) was reflected in an increase in copepod biomass for the entire West Coast since the 1970s (Huggett et al. 2009). Since the mid-1990s, the long-term increasing trend in zooplankton abundance in St Helena Bay has reversed (Figure 5), but this pattern is not uniform along the West Coast and western Agulhas Bank. These changes as well as changes in the size structure of the zooplankton community are thought to result locally from both bottom-up forcing by environmental fluctuations and varying top-down predation pressure and selectivity of small pelagic fish species (Hutchings et al. 2006, Huggett et al. 2009, Hutchings et al. 2012). Gelatinous zooplankton, regarded as sentinel groups signalling large-scale changes in marine ecosystems (Hay 2006), have shown no consistent changes in abundance in St Helena Bay over the period 1988-1997, although warm periods were associated with distinctly different taxa than cold periods (Buecher and Gibbons 2000).

One of the best-documented changes in distribution that has occurred off South Africa is for commercially and trophically important small pelagic fish species (sardine and anchovy). Their population sizes are naturally variable, with both species exhibiting a positive relationship between stock size and distributional area (Barange et al. 1999, van der Lingen et al. 2006a), so that changes in population size affect spatial extent. Sardine biomass increased from reduced levels in the late 1990s, peaking at more than 4 million tonnes in 2002 but decreasing again by 2008 (Coetzee et al. 2008). Anchovy biomass increased from a low in 1996 to peak in 2001, after which it remained relatively high (Fairweather et al. 2006). Since data collection began in 1985, the bulk of both anchovy and sardine biomass has been found on the West Coast, but since 1997 and 1999 respectively, the greater proportion of biomass has been found east of Cape Agulhas (van der Lingen et al. 2002, Roy et al. 2007, Coetzee et al. 2008). A recent decrease in sardine population size is believed to be the result of poor recruitment since 2004, an unexplained increase in adult mortality (i.e. not caused by fishing) and a spatial mismatch between fishing effort and sardine biomass, resulting in high exploitation rates west of 
Cape Agulhas (Coetzee et al. 2008). The cause of the spatial mismatch was a relative increase in sardine biomass east of Cape Agulhas in the late 1990s, attributed to a combination of disproportionately large spawning and recruitment success during the late 1990 s/early 2000s and a natal-homing effect (Coetzee et al. 2008). It is also possible that there are two sardine stocks, each favouring different coasts for spawning (Coetzee et al. 2008). For anchovy, environmental mediation is suggested as the cause of the increased proportion found east of Cape Agulhas since 1996, which has been linked to inshore cooling and a change in the local food environment (Roy et al. 2007).

For the main piscivorous fish species off South Africa, there have been observed changes in abundance but most of these have been attributed to fishing pressure. All exploited species have decreased markedly in abundance since commercial fishing started (Table 2), but there are also recent changes that are not easily attributed simply to bulk biomass removal by fishing. Average abundance of both hake species appeared to be lower during the 2000s than during the 1990s, based on summer/autumn survey data (Rademeyer et al. 2008). Other demersal species were also affected, and size-based indicators showed a decrease between 1986 and 2003 as a direct result of fishing pressure (Yemane et al. 2008). Survey data from 1986 to 2009 indicated changes in demersal fish assemblages on the West Coast in 1992 and 2003/2004, corresponding to periods when shifts were noted in West Coast rock lobsters and pelagic fish species (Atkinson et al. 2011a). Fast-growing, early-maturing demersal species increased in abundance and slow-growing, latematuring species decreased (Atkinson et al. 2011a), as is generally predicted to result from fishing. However, fishing pressure was relatively stable when these shifts occurred, and the changes are believed to be the result of indirect fishing effects in combination with environmental fluctuations (Atkinson et al. 2011a).

Hake and other demersal species did not appear to increase in biomass on the South Coast to match the increase observed in major prey species (small pelagic fish) in the 2000s (van der Lingen et al. 2006a). In contrast, Atlantic-based albacore tuna Thunnus alalunga abundance off South Africa seems to have been decreasing since the late 1990 os whereas that of yellowfin tuna T. albacares, originating in the Indian Ocean, appears to have increased, which could be in response to the increase in easterly bio-mass of small pelagic fish (van der Lingen et al. 2006b). 


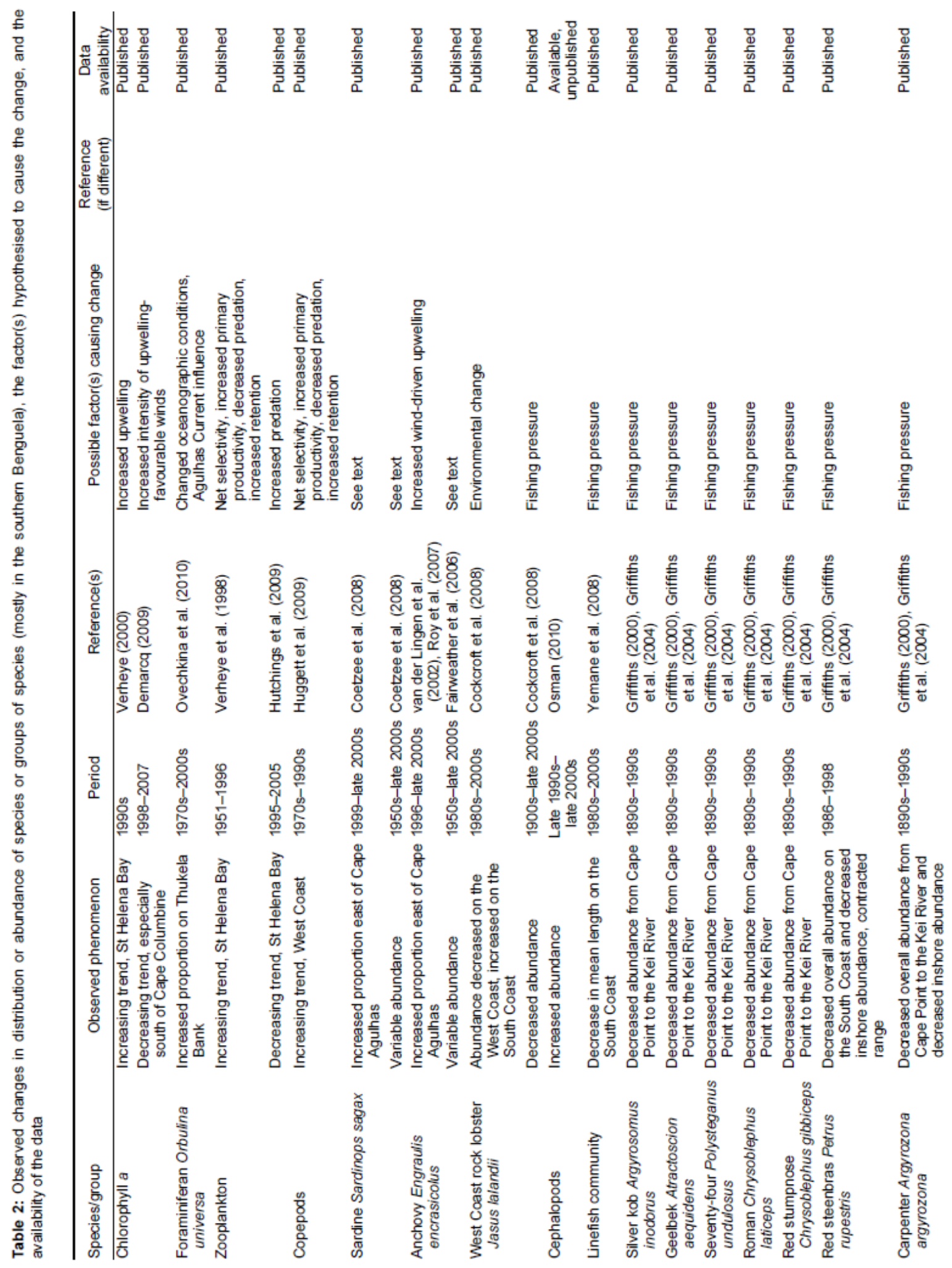




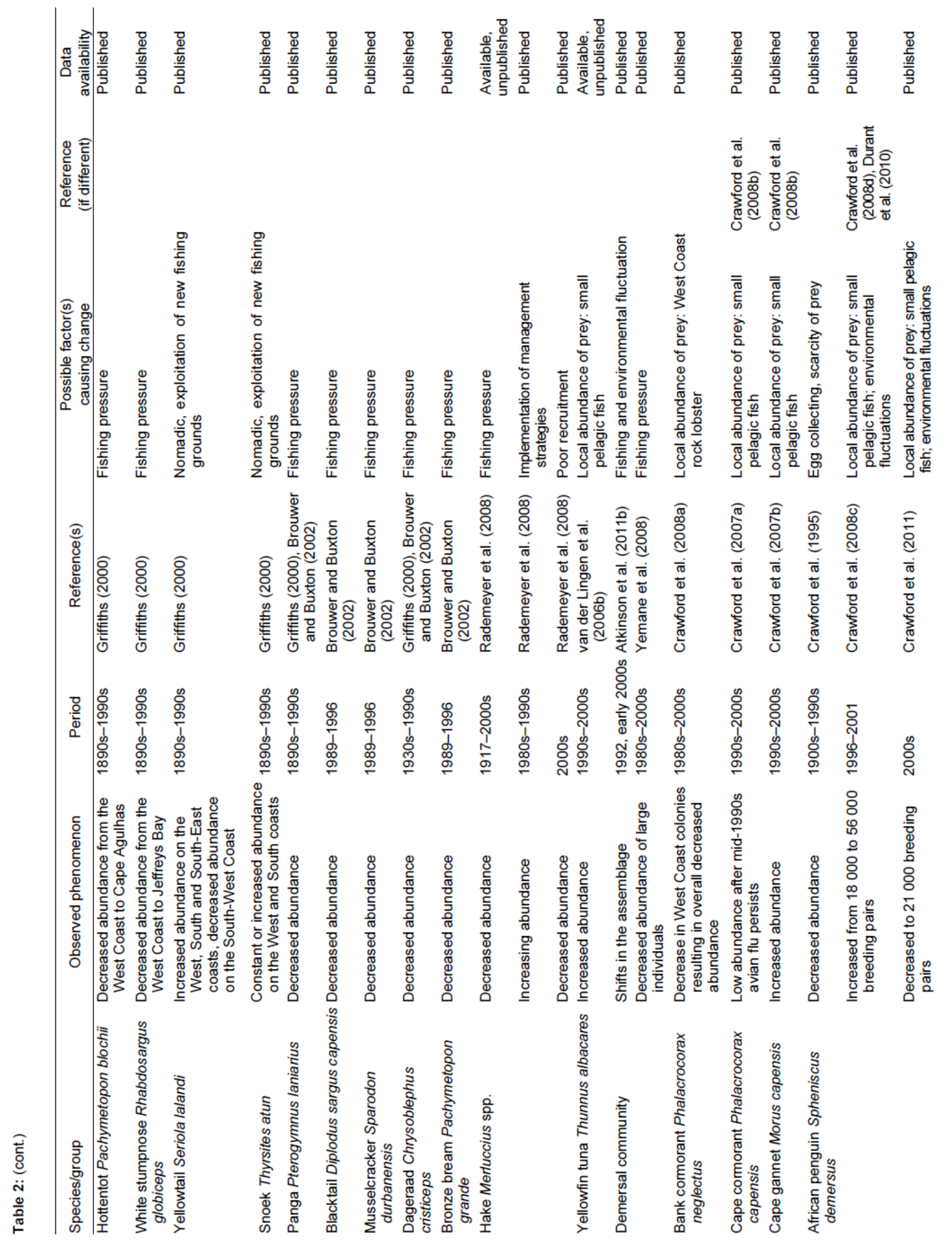




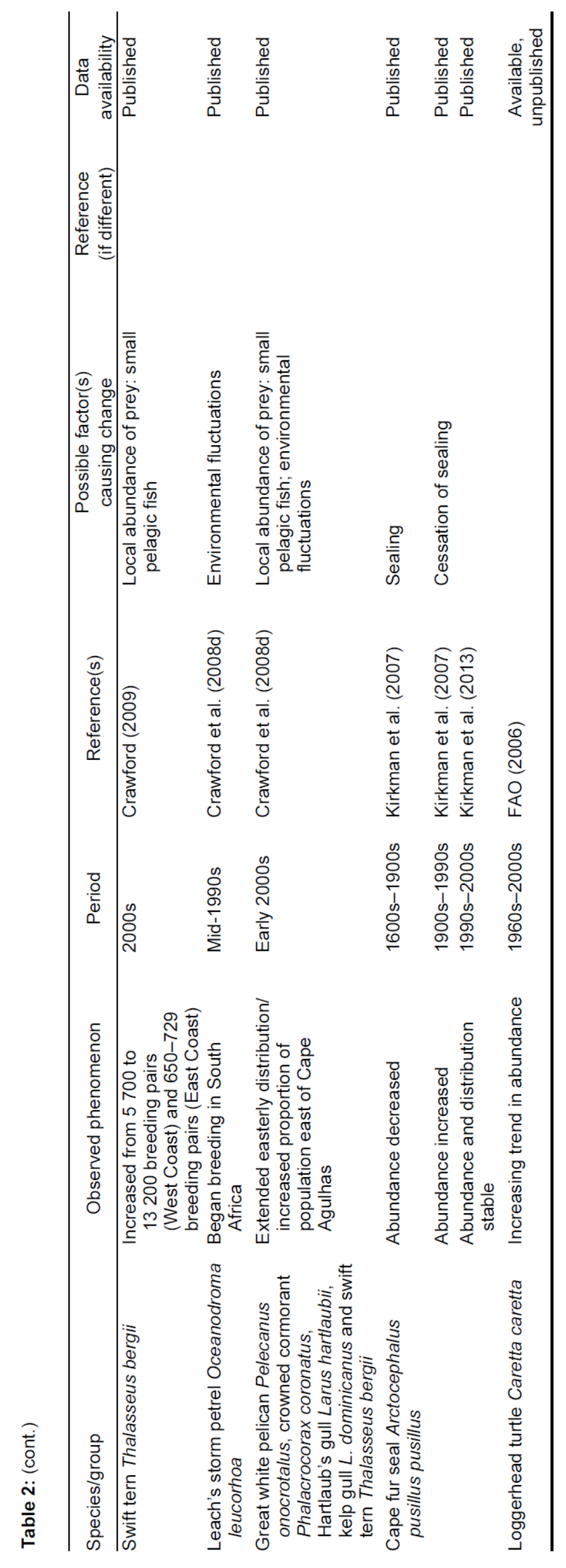

https://repository.uwc.ac.za 
The greatest impacts on most linefish species have been by fishing, although this has possibly been exacerbated recently by environmental changes. By the 1990s catches per unit effort (an index of abundance) of a number of the slow-growing teleost species targeted by the linefishery in the Western Cape had decreased well below sustainable levels (Table 2; Griffiths 2000, Griffiths et al. 2004). The sparid seventy-four Polysteganus undulosus has been considered commercially extinct since before the fishery was closed in 1998 (Chale-Mastau et al. 2001). Size structures of communities also have been affected, with decreases in mean length associated with increased fishing pressure, except in the case of snoek Thyrsites atun (Yemane et al. 2004). More nomadic species (snoek and yellowtail Seriola lalandi) have been less impacted by fishing and do not appear to have undergone notable changes in distribution or abundance (Table 2; Griffiths 2000, Griffiths et al. 2004), although an increase in snoek biomass since the 1980 s has been suggested, based on calculations from mass-balanced ecosystem models of the southern Benguela compared over different time periods (Osman 2010).

Decreases in catch per unit effort, to the point of severe depletion in some cases, also have been recorded off the Eastern Cape (Table 2; Griffiths 2000, Brouwer and Buxton 2002). Similar patterns are evident in the KwaZulu-Natal linefish fisheries, where total catch and catch per unit effort have decreased since the early 1900s, with most resident species now overexploited (Penney et al. 1999, Mann 2000). Current catch composition shows an increased contribution from small rather than large reef fish species and shoaling migrant species and, as in Cape waters, a decrease in large reef dwellers such as seventy-four, red steenbras Petrus rupestris and rock cods (Penney et al. 1999).

Clark (2006) had speculated that under climate change, fish species on the East Coast should occupy waters farther south, whereas species on the West Coast might be displaced to greater depths or become restricted to the immediate vicinity of upwelling. There have been changes in depth distributions of some species but these have been attributed to fishing pressure. Species whose depth distributions increase with age, such as red steenbras and carpenter Argyrozona argyrozona, have undergone offshore shifts in adult abundance as their inshore stocks have been depleted by fishing. The range of red steenbras has also contracted around the coast as stocks in areas with a longer history of exploitation are fished down, leaving abundance off the Transkei Coast highest (Griffiths 2000). More recently, however, warming in the Agulhas Current region on the east coast of South Africa has been shown to coincide with increased abundance and diversity of tropical species at subtropical reefs off KwaZulu-Natal (Lloyd et al. 2012). These results support the predictions of poleward range expansions and increased species richness as sea temperatures increase (Lloyd et al. 2012).

A large number of seabird species have undergone changes in distribution or abundance since the 1990 s (Table 2). Suggested causes of these changes are climate impacts and food availability. Crawford et al. (2008a) showed that changes in seabird populations off South Africa have been similar to those observed off Marion Island and elsewhere, attributing these changes to climate change. Site-faithful, long-lived species, such as Cape gannet, have been shown to be particularly susceptible to local extinctions as a result of environmental change (Pichegru et al. 2010). The local availability of prey has also impacted seabirds, with species with small foraging areas or fixed breeding localities 
(African penguins, Cape gannets and Cape cormorants Phalacrocorax capensis) being more susceptible than widely ranging species such as the swift tern Thalasseus bergii (Crawford et al. 2008a, 2008b, 2008c, 2008d, Crawford 2009). Another important factor impacting seabird population numbers is predation. Colonies of African penguins and bank cormorants $P$. neglectus at Lambert's Bay, previously the northernmost colonies for both species in the Western Cape, have been considered extinct since 2006 (Crawford et al. 2008a) and 1999 (Crawford et al. 2008b) respectively, partly as a result of local predation by Cape fur seals Arctocephalus pusillus pusillus. In 2003, African penguins established a new colony at De Hoop, but land-based predation caused numbers to drop (Underhill et al. 2006, Crawford 2007). At Lambert's Bay, breeding was abandoned by the Cape gannet colony in 2006, attributed by Crawford et al. (2007a) to predatory attacks by Cape fur seals. Breeding subsequently resumed (Distiller et al. 2012) following the introduction of management measures to reduce seal-seabird interactions at the colony.

In contrast to many fish species, which have decreased in abundance as a result of fishing, marine mammals have tended to remain constant or increase in abundance over the past decades because of a cessation of harvesting in combination with other factors. The Cape fur seal population was estimated at 2 million in 1993, approximately $40 \%$ of which resided in the southern Benguela with the remaining majority found in Namibia (Butterworth et al. 1995, Kirkman et al. 2007). Since 1993, distribution and abundance of the Cape fur seal in the southern Benguela have remained relatively stable (Kirkman et al. 2013), and did not reflect the increase in small pelagic fish biomass in the early 2000 or or the increase in relative distribution of these prey species on the South Coast. It is likely that limited suitable space for the expansion of breeding, particularly along the South Coast, contributed to this stability (Kirkman et al. 2013). However, since the 1990 os a fur seal colony on the Robberg Peninsula that was harvested to extinction in the 1800 s has been recolonised and is expanding, coinciding with an increase in small pelagic fish in the area (Huisamen et al. 2011). Conversely, abundance on the South-East Coast of Bryde's whales Baleanoptera edeni, which also prey on small pelagic fish, appears to have decreased since the 1980s (Best 2001, Penry et al. 2011), possibly because of small-scale, local fluctuations (Penry et al. 2011). Numbers of southern right whales Eubalaena australis have continued to recover at a rate of approximately $7 \%$ annually since monitoring began in the 1970s (Best et al. 2001, Brandão et al. 2010) and there has been an increase in humpback whales Megaptera novaeangliae migrating through the coastal waters of KwaZulu-Natal since the late 1980s (Findlay et al. 2011). On the West Coast there are approximately 500 humpback whales that are temporarily resident during spring and summer when they feed (Barendse et al. 2011). Dolphin abundance in the southern Benguela is not well known and, although some population-level studies have been undertaken (e.g. Elwen et al. 2009), there is a lack of long-term abundance data. Populations of loggerhead turtles Caretta caretta show a significant increase since the 1960 , when a nesting site monitoring and protection programme was introduced on the KwaZulu-Natal beaches (FAO 2006). The nesting population of leatherback turtles Dermochelys coriacea has remained unchanged ( $\mathrm{Nel} 2009$ in Brazier et al. 2012).

\section{Changes in timing/phenology}

Changes in timing of specific ecological processes might be expected when local conditions change as a result of climate change. Off South Africa, the lack of time-series 
data showing intra-annual conditions in shelf and benthic ecosystems makes it difficult to detect any changes in plankton groups if they are occurring. However, top predators can act as sentinel species, integrating and responding to environmental change with a greater likelihood of being detected than small species. Durant et al. (2010) related changes in the timing of breeding of African penguins and their growth rates on Dassen Island to the Southern Oscillation Index and SSTs at breeding and prey-spawning grounds. The African penguins at Dassen Island bred approximately one month earlier during the period 2004-2008 than they did from 1995 to 2001 (Durant et al. 2010). The change was attributed to warmer temperatures. However, this response had a knock-on effect because the penguins went on to exhibit reductions in per capita growth rates. This was believed to be a result of temporal mismatches in winter between the penguin predators and their prey, which are young-of-the-year pelagic fish (Durant et al. 2010). Changes in phenology at one trophic level can thus have unexpected results at other trophic levels, with both positive and negative feedbacks possible.

\section{Changes in community composition}

The species richness of zooplankton communities changes around the South African coastline in a manner consistent with changes in biogeography. There are peaks in the tropical and subtropical waters of the East Coast and troughs are obvious in the coldtemperate waters along the West Coast (Gibbons et al. 1995, 2010). Fish communities also show changes in richness around the coast (Turpie et al. 2000), although distributional peaks in endemism vary with taxa. Cross-shelf changes in demersal fish communities linked to bathymetry are pronounced (Yemane et al. 2010), with distinct assemblages associated with different depth strata (Fennessy and Groeneveld 1997, Walmsley et al. 2007, Attwood et al. 2011). Information on depth-related changes in other taxa is restricted to sponges along the East Coast, which, like demersal fish, decrease in richness with increasing depth (Samaai et al. 2010).

In contrast to our understanding of spatial changes in species richness and evenness around South Africa, our knowledge about temporal changes in either of these community attributes is limited. In the case of zooplankton, there is a coupling between oceanography and diversity measures, with cool, recently upwelled water tending to support assemblages of lower diversity than warm, stratified water. This should be reflected in seasonal changes to communities, although there are few studies that have explored this. In the case of fish communities, there is little evidence of seasonality in the species composition of demersal catches along the West Coast overall (Atkinson et al. 2011b, but see Roel 1987), although limited data suggest that some species could move inshore and offshore on a seasonal basis (Atkinson et al. 2011b).

Studies of changes in community composition at interannual scales are scarce, and their results need to be interpreted with caution. In the absence of standardisation (such as occurs, for example, in continuous plankton recorder surveys [Richardson et al. 2006]) or calibration, there are marked effects on estimates of species diversity caused by interannual changes in survey protocols, survey design, sampling gears (e.g. Atkinson et al. 2011b) and both taxonomy and taxonomic expertise (e.g. Bianchi et al. 2000). Such issues in part complicated the conclusions of Atkinson et al. (2011b), who noted two changes in the composition of demersal fish assemblages along the west coast of South 
Africa. The first of these occurred in the early $1990 \mathrm{~s}$ and the second in the mid 2000s, with the latter confounded by changes in sampling gear. Although Atkinson et al. (2011b) did not examine richness or evenness of the fish fauna specifically, it is clear that evenness at least will have changed because of changes in relative abundance of different species among the three periods. In the absence of major changes in fishing pressure over the study period (1986-2009), these authors attributed the changes to 'long-term indirect effects of fishing (e.g. species replacements, trophic cascades, habitat modification) in combination with environmental changes' (Atkinson et al. 2011b, p 169). Their arguments for environmental change reflect the fact that the later changes are coincident with the abovementioned eastward shift for pelagic fish and rock lobster (Mead et al. 2013).

Other studies have explicitly attributed long-term changes in composition of fish communities to fishing. Using discrete time-series within a 100-year dataset collected from the Cape coastline (Kei River to Orange River), Yemane et al. (2004) showed significant changes in linefish catch assemblages. Increases in the number of linefish species were observed along the South-East and South coasts and a decrease along the West Coast. The South-West Coast showed no obvious change. These changes reflect changes in the dominant species caught, which in turn reflects fishing pressure. In the cool-temperate Western Cape region, catches have become dominated by a single, fastgrowing species (snoek), whereas catches on the warm-temperate South Coast have become more diverse over time (Griffiths 2000, Yemane et al. 2004) as previously preferred fish species (geelbek Atractoscion aequidens and silver kob Argyrosomus indorus) have been depleted. Similar increases in diversity and richness were observed by Yemane et al. (2010) in a study of demersal fish assemblages off the South Coast over the period 1988-2003. The changes were attributed to the differential impact of exploitation on different species (Griffiths 2000).

Using a foodweb model of the southern Benguela fitted to time-series data (catch and abundance), Shannon et al. (2009) suggested there was no overall change in biomass diversity over the period 1978-2003, although it steadily increased from 1978 to 2000 before decreasing markedly to 2003. During the same period, the trophic level of the community decreased. These patterns were probably influenced by a large peak in biomass of small pelagic fish in the early 2000s, which would have caused biomass diversity and mean trophic level to decrease. Biomass diversity would have increased in the early period as dominant species were reduced by fishing.

Species richness on the East Coast has increased as a result of range extensions of tropical fish species to the south. For example, off the Pondoland Coast, a subtidal (1-30 m) ichthyofaunal survey yielded 138 species from 49 families, with 30 species from 15 families representing range extensions to the south (Mann et al. 2006). Farther south, James et al. (2008) reported the appearance of several tropical fish species in a warmtemperate estuary on the South-East Coast from 1998 to 2006. The authors attributed these southward range extensions to increasing local SSTs over this period.

\section{Ecosystem dynamics and dominant foodweb pathways}

Short- and long-term (Kirby and Beaugrand 2009) shifts in dominant trophic pathways have been documented for a variety of marine ecosystems (Moloney et al. 2010). Some of 
these shifts have been shown to reverse relatively quickly, but other ecosystems have not reverted to their previous states over time (Jarre and Shannon 2010). At least two marked marine ecosystem changes occurred in southern Africa during the past few decades (Hutchings et al. 2009), one off Namibia and one off South Africa. These changes have variously been explained by overfishing (off Namibia; Boyer et al. 2001), spatially biased fishing mortality (off South Africa; Coetzee et al. 2008), and changed environmental conditions (van der Lingen et al. 2006a, Roy et al. 2007, Coetzee et al. 2008).

The Namibian pelagic ecosystem changed dramatically with the collapse of stocks of small pelagic fish in the late 1960s, resulting in the proliferation of jellyfish, increased abundance of a key species (bearded goby Sufflogobius bibarbatus), and major changes in seabird and marine mammal predator populations (Cury and Shannon 2004, van der Lingen et al. 2006a). Off South Africa, large-scale spatial changes occurred in the abundance of important species off the South and West coasts, including commercially important small pelagic fish species (sardine and anchovy) and rock lobsters (van der Lingen et al. 2006a). Species of conservation importance, such as African penguins and Cape gannets, also exhibited large changes in relative abundance along the coastline, probably as a result of changes in their prey resources (van der Lingen et al. 2006a).

These concurrent changes in species abundances and distributions in the southern Benguela reflect complex alterations to the functioning of the ecosystem. Balanced trophic models for 1900, 1960, 1980 and 2004-2008 required an overall decrease in biomass of large fish (adult hake and large pelagic fish) and an increase in biomass of planktivorous fish by the 2000s following an initial decrease to the 1980s (Shannon et al. 2003, Watermeyer et al. 2008, Osman 2010). Ecosystem-level indicators based on data from 1986 to 2005 showed that overall biomass of the community increased but the proportion of predatory fish and the average trophic level decreased (Bundy et al. 2010). Analyses using decision-trees indicated that the overall state of the southern Benguela ecosystem had decreased since the 1980 os (Bundy et al. 2010). Diversity indices decreased from theoretical, historical 'pristine' levels to the 1960s, but were greater in the 2000 s compared with the 1960s, probably as a result of high small pelagic fish biomass in the most recent period (Watermeyer et al. 2008). An index of the overall health of seabirds in South Africa, derived from population estimates for 10 dominant species from the 1950 s to 1999 , increased from the 1950 s to the 1970 s then decreased to the 1990s, with an overall decrease of 5-12\% over the whole period (Underhill and Crawford 2005).

The times at which ecosystem changes were triggered, and their ultimate causes, are difficult to identify unambiguously because of lagged effects and differences in life-history parameters among dominant species and affected groups. This is similar to observations made in the North Sea, where the exact years of the change vary according to the group(s) used to illustrate the change (Beaugrand 2004). Howard et al. (2007) applied a statistical method to long-term South African datasets and identified two periods that might signal the onset of major ecosystem changes since 1950. The first occurred during the 1960s, attributed to heavy fishing pressure but with some environmental forcing. The second change occurred in the early 200os, attributed mainly to environmental forcing. Fishing pressure was identified by Mackinson et al. (2009) as the primary driver of change at 
an ecosystem level in the southern Benguela, based on an ecosystem model constructed to represent the period 1978-2002 (Shannon et al. 2004).

A number of modelling studies have investigated possible effects of global change on South African marine ecosystems. Smith and Jarre (2011) used a frame-based modelling approach to represent different scenarios of relative abundance of sardine and anchovy, assumed to result from different environmental drivers. The authors found that fishing could cause changes in states, but these occurred more readily if environmental triggers were used as well. A similar result was obtained by Heymans et al. (2004) and Watermeyer et al. (2008), whose results from trophic ecosystem models showed that fishing appeared to reduce the resilience of the ecosystem to environmental perturbations. There are complex interactions in ecosystems and these make it difficult to disentangle causes and effects, even when the ecosystems are represented by simplified ecosystem models.

Along the east coast of South Africa, the shelf ecosystems are likely to be responsive to fishing and to changes in river flows, either through river management or through changes in rainfall over the continent. Changes in river flows would affect riverine inputs to the shelf ecosystems, which are detritus-driven rather than phytoplankton-driven (Ayers and Scharler 2011). Crustacean and linefish fisheries of the Thukela Banks could be impacted by reduced flows, with the commercial linefishery projected to have a $20 \%$ reduction in catch and a $17 \%$ reduction in annual value under extreme flow reduction scenarios (Turpie and Lamberth 2010). The prawn fishery would probably experience limited economic effects because it is buffered by having large diversity in the bycatch and important contributions by catches offshore that are not affected by river flow in the short term (Turpie and Lamberth 2010).

In general, off South Africa, the strong signals that have been observed in marine ecosystems and the good understanding that exists of ecosystem functioning have not provided clarity on the drivers of observed changes, their triggers or the likelihoods of their persistence. It has been possible to document some changes and to infer possible causal mechanisms for past and projected future changes. However, without improved monitoring systems and longer time-series of environmental and biological data, it will be difficult to unequivocably identify and understand future observed changes or to predict their consequences with any degree of confidence.

\section{Adaptability to change}

Some possible and unpredictable consequences of global change involve the abilities of organisms to adapt to changes in their biotic and abiotic environments (Moloney et al. 2011). These adaptations can be behavioural or involve changes in phenotype or genotype. A common behavioural adaptation is to simply move from unfavourable to favourable areas, changing the distributions of many species. Other species have inherent abilities to adapt quickly, because they occur naturally in dynamic marine environments. These species could retain their current large-scale distributions but alter other aspects of their biology or ecology, with knock-on effects in the ecosystem. 
In the dynamic coastal upwelling region off southern Africa, there are a number of examples of species pairs where each member of the pair appears to be adapted in fundamentally different ways to continually changing environments. For copepods, Huggett et al. (2007) investigated the factors influencing the relative abundance on the West Coast and Agulhas Bank of Calanoides carinatus and Calanus agulhensis. They found the two species responded in similar ways to temperature, food concentration, food size and type but differently to variability in food abundance. Calanus agulhensis recovered quickly from short periods of starvation but Calanoides carinatus recovered quickly from long periods without food. Thus, the two species appear to be adapted to variability at different time-scales. Sardine and anchovy are similarly suited to variable environments but their populations off southern Africa appear to vary at different timescales. The longer lifespans of sardine, their omnivorous diet and their ability to filterfeed smaller plankton than anchovy allow their populations to respond to decadal-scale variability, whereas anchovy populations are more closely linked to interannual variability (van der Lingen et al. 2006a). Sardine also display variability in body shapes and vertebral counts, possibly in response to environmental cues (Wessels 2009).

Another important species pair off the West Coast is that of the Cape hakes. This is the only region in the world where two hake species have similar latitudinal distributions, being separated mainly by depth (Lloris et al. 2005). Wilhelm (2012) used studies of otoliths of $M$. capensis off Namibia to conclude that this species was faster-growing than had previously been assumed. These results were underpinned by the hypothesis that $M$. capensis occupies a niche that allows the species to react quickly to short-term variability in the pelagic and demersal environments, similar to anchovy and Calanus agulhensis. In contrast, the slower- growing $M$. paradoxus relies on longer-term variability to produce good year-classes that sustain the population over many years (Wilhelm 2012), as has been suggested for sardine and Calanoides carinatus.

On the East Coast, James et al. (2007) compared the impacts of intermittent opening of estuaries on two fish species that require these habitats as juveniles for at least the first year of life. They concluded that white steenbras Lithognathus lithognathus was more susceptible to changes in estuary opening-closing than Cape stumpnose Rhabdosargus holubi, illustrating again that not all species are likely to be impacted in the same ways by global change. It would be useful to include information on species-level characteristics in ecosystem models, so as to capture some of the basic differences that exist among species in their biological and ecological attributes. In this way it might be possible to capture some of the interplay among species diversity and trophic flows in ecosystems, improving the ability to understand and predict potential plausible ecosystem states.

\section{Synthesis}

In reviewing the evidence for long-term changes in South Africa's offshore marine ecosystems it was clear that there are insufficient baseline data to disentangle short- and medium-term variability from long-term change. Where large-scale ecosystem changes have been observed, it was generally not possible to attribute these changes to specific pressures. The current state of understanding mainly involves untested hypotheses based on incomplete data, but with relatively good understanding of the processes involved, and model-assisted interpretations of the complex interactions. 


\section{The need for baseline data and continuous monitoring}

It is clear that changes are occurring in the pressures on the marine environment (Fréon et al. 2005) but it is difficult to quantify these and, in some instances, it is not clear what data are available. Important, unidirectional drivers, such as the increase in atmospheric carbon dioxide, are measured on a global scale. However, their regional impacts are difficult to identify because there are few baseline values from shelf waters to compare with current and future measurements. Other notable knowledge gaps include the effects of ocean acidification on South African ecosystems as opposed to individual species, adaptation responses of species groups over realistic, long time-scales and the effects of $\mathrm{pH}$ on metal-organic interactions.

There are few historical records of seawater quality in South Africa to use as baselines for tracking changes and possible impacts of organic and other pollutants. For trace metals there are also difficulties associated with accurate sampling and measurement, for which the employment of clean techniques is relatively recent (Cutter et al. 2010). The sparse data that exist on pollutants tend to be better represented from the East Coast than the West Coast, but these data are patchy in space and time. The general paucity of measurements and difficulties in accessing what data there are make it difficult to draw many conclusions on the role of marine pollution as a significant pressure in South Africa's marine ecosystems and long-term trends cannot be identified. There is also limited understanding of eco-toxicological effects and impacts on marine life. In the case of impacts of offshore mining operations, it would be useful if the data collected by private and parastatal license holders during their mandatory environmental monitoring programmes were to be standardised and centralised. Some companies are relatively transparent and open in this regard, but others are not. This should change; the companies have access to financial resources for monitoring the environment that the regional and national governments cannot match for this purpose.

In contrast to the situation for pollution, mining and ocean acidification pressures, there has been reasonably good information available for many fisheries and it is possible to track the history of fisheries exploitation in South African marine ecosystems. There are also good data available for some commercially important species and those of conservation interest. However, data on plankton are patchy in space and time, and confounded by changes in sampling methods and identification skills. Many of the data gaps can be partly filled through the use of models, and mass-balance models have been particularly useful in constraining likely biomass ranges for species that are poorly known (e.g. Watermeyer et al. 2008).

\section{The need for coherent ecosystem projects}

This study was motivated by the need to synthesise information from projects funded through the South African Network for Coastal and Oceanic Research's SEAChange programme under the 'Ecosystems and Change' theme (SANCOR 2006). The results of some of these projects were used, but there was limited coherence among them, possibly because project proposals are prepared by principal investigators who are effectively in competition for limited funding with their potential collaborators. As a result, some obvious gaps were not addressed and it was difficult to use the results in a coordinated 
fashion. There is also very limited understanding of how primary productivity and the structures of phytoplankton communities might be changing in response to changes in ocean temperatures, despite the fundamental importance of primary production in ecosystem models. Some of these issues are likely related to limited resources and the difficulties of carrying out ship-based research, but they also reflect the difficulties of designing appropriate research projects for ecosystem-level issues when the funding is allocated to individual principal investigators.

To understand the impacts of global change requires good long-term datasets and the ability to unambiguously identify change and the causes of that change. At present, the time-series off South Africa are mostly too short and the data too sparse to meet conditions for attributing observed changes to causal processes. It is difficult to distinguish between speculation and evidence-based change, especially as the latter often is associated with large uncertainties. However, it is important to continue documenting changes that have been observed, searching for patterns in observations, identifying consistency in hypotheses to explain observed changes and testing these hypotheses through future observations and analyses. A coordinated approach is needed to ensure that the right data are effectively collected, archived and managed so future generations have an informed basis on which to make decisions relating to the marine and coastal environment.

Acknowledgements - The theme for this manuscript was suggested by the Programme Management Committee of the South African Network for Coastal and Oceanic Research's SEAChange programme. It was made possible by the award of a Knowledge Fields Grant from the South African National Research Foundation. 


\section{References}

Adams NJ. 1994. Patterns and impacts of oiling of African penguins Spheniscus demersus: 1981-1991. Biological Conservation 68: 35-41.

Altwegg R, Crawford RJM, Dyer BM, Underhill LG, Upfold L, Williams AJ. 2008. Long term survival of de-oiled Cape gannets Morus capensis after the Castillo de Bellver oil spill of 1983. Biological Conservation 141: 1924-1929.

Andrady AL. 2011. Microplastics in the marine environment. Marine Pollution Bulletin 62: 1596-1605.

Atkinson LJ, Field JG, Hutchings L. 2011a. Effects of demersal trawling along the west coast of southern Africa: multivariate analysis of benthic assemblages. Marine Ecology Progress Series 430: 241-255.

Atkinson LJ, Leslie RW, Field JG, Jarre A. 2011b. Changes in demersal fish assemblages on the west coast of South Africa, 1986-2009. African Journal of Marine Science 33: 157-170.

Attwood CG, Petersen SL, Kerwath SE. 2011. Bycatch in South Africa's inshore trawl fishery as determined from observer records. ICES Journal of Marine Science 68: 21632174.

Ayers MJ, Scharler UM. 2011. Use of sensitivity and comparative analyses in constructing plausible trophic mass-balance models of a data-limited marine ecosystem - The KwaZulu-Natal Bight, South Africa. Journal of Marine Systems 88: 298-311.

Bakun A, Weeks SJ. 2008. The marine ecosystem off Peru: what are the secrets of its fishery productivity and what might its future hold? Progress in Oceanography 79: 290299.

Barange M, Field JG, Harris RP, Hofmann EE, Perry RI, Werner FE (eds). 2010. Marine ecosystems and global change. Oxford: Oxford University Press.

Barange M, Hampton I, Roel BA. 1999. Trends in the abundance and distribution of anchovy and sardine on the South African continental shelf in the 1990s, deduced from acoustic surveys. South African Journal of Marine Science 21: 367-391.

Barendse J, Best PB, Thornton M, Elwen SH, Rosenbaum HC. 2011. Transit station or destination? Attendance patterns, movements and abundance estimate of humpback whales off west South Africa from photographic and genotypic matching. African Journal of Marine Science 33: 353-373.

Beaugrand G. 2004. The North Sea regime shift: Evidence, causes, mechanisms and consequences. Progress in Oceanography 60: 245-262.

Beaugrand G. 2009. Decadal changes in climate and ecosystems in the North Atlantic Ocean and adjacent seas. Deep-Sea Research II 56: 656-673.

Best PB. 2001. Distribution and population separation of Bryde's whale Balaenoptera edeni off southern Africa. Marine Ecology Progress Series 220: 277-289.

Best PB, Brandão A, Butterworth DS. 2001. Demographic parameters of southern right whales off South Africa. Journal of Cetacean Research and Management: Special Issue 2: 161-169.

Best PB, Crawford RJM, van der Elst RP. 1997. Top predators in southern Africa's marine ecosystems. Transactions of the Royal Society of South Africa 52: 177-225.

Bianchi G, Gislason H, Graham K, Hill L, Jin X, Koranteng K, Paya I, Sainsbury K, Sanchez F, Zwanenburg K. 2000. Impact of fishing on size composition and diversity of demersal fish communities. ICES Journal of Marine Science 57: 558-571. 
Borges AV, Gypens N. 2010. Carbonate chemistry in the coastal zone responds more strongly to eutrophication than to ocean acidification. Limnology and Oceanography 55: $346-353$.

Boyer DC, Boyer HJ, Fossen I, Kreiner A. 2001. Changes in abundance of the northern Benguela sardine stock during the decade 1990-2000, with comments on the relative importance of fishing and the environment. South African Journal of Marine Science 23: 67-84.

Branch GM, Clark BM. 2006. Fish stocks and their management: the changing face of fisheries in South Africa. Marine Policy 30: 3-17.

Brandão A, Best PB, Butterworth DS. 2010. Estimates of demographic parameters for southern right whales off South Africa from survey data 1979 to 2006. Unpublished report (SC/62/BRG30) presented to the International Whaling Commission. Cambridge, UK.

Brander KM. 2007. Global fish production and climate change. Proceedings of the National Academy of Sciences of the USA 104: 19709-19714.

Brazier W, Nel R, Cliff G, Dudley S. 2012. Impact of protective shark nets on sea turtles in KwaZulu-Natal. South Africa, 1981-2008. African Journal of Marine Science 34: 249257.

Brouwer SL, Buxton CD. 2002. Catch and effort of the shore and skiboat linefisheries along the South African Eastern Cape coast. South African Journal of Marine Science 24: 341-354.

Brown AC. 1997. John D.F. Gilchrist and the early years of marine science in South Africa. Transactions of the Royal Society of South Africa 52: 3-16.

Brown CJ, Fulton EA, Hobday AJ, Matear RJ, Possingham HP, Bulman C, Christensen V, Forrest RE, Gehrke PC, Gribble NA, Griffiths SP, Lozano-Montes H, Martin JM, Metcalf S, Okey TA, Watson R, Richardson AJ. 2010. Effects of climate-driven primary production change on marine food webs: implications for fisheries and conservation. Global Change Biology 16: 1194-1212.

Buecher E, Gibbons MJ. 2000. Interannual variation in the composition of the assemblages of medusae and ctenophores in St Helena Bay, Southern Benguela Ecosystem. Trends in Hydrozoan Biology 64: 123-134.

Bundy A, Shannon LJ, Neira S, Shin Y, Hill L, Aydin K. 2010. The good (ish), the bad, and the ugly: a tripartite classification of ecosystem trends. ICES Journal of Marine Science 67: 745-768. Butterworth S. 1983. Assessment and management of pelagic stocks in the southern Benguela region. In: Sharp GD, Csirke J (eds), Proceedings of the expert consultation to examine changes in abundance and species composition of neritic fish resources, April 1983, San José, Costa Rica. FAO Fisheries Report 291, Vol. 2.

Rome: Fish and Agriculture Organization. pp 329-405.

Butterworth DS, Punt AE, Oosthuizen WH, Wickens PA. 1995. The effects of future consumption by the Cape fur seal on catches and catch rates of the Cape hakes. 3 . Modelling the dynamics of the Cape fur seal Arctocephalus pusillus pusillus. South African Journal of Marine Science 16: 161-183.

Carter R. 2006. Environmental investigation programme to determine potential cumulative effects of outfalls and discharges to the sea off the KwaZulu-Natal coast. Unpublished report prepared for Coastwatch, Wildlife and Environment Society of South Africa. Lwandle Technologies, Cape Town. 
Chale-Mastau J, Govender A, Beckley LE. 2001. Age, growth and retrospective stock assessment of an economically extinct sparid fish, Polysteganus undulosus, from South Africa. Fisheries Research 51: 87-92.

Checkley DM, Alheit J, Oozeki Y, Roy C (eds). 2009a. Climate change and small pelagic fish. Cambridge: Cambridge University Press.

Checkley DM, Dickson AG, Takahashi M, Radich, JA, Eisenkolb N, Asch R. 2009b. Elevated $\mathrm{CO}_{2}$ enhances otolith growth in young fish. Science 5935: 1683-1683.

Cheung WWL, Lam VWY, Sarmiento JL, Kearney K, Watson R, Pauly D. 2009. Projecting global marine biodiversity impacts under climate change scenarios. Fish and Fisheries 10: 235-251.

Clark BM. 2006. Climate change: a looming challenge for fisheries management in southern Africa. Marine Policy 30: 84-95.

Cochrane KL, Butterworth DS, Payne AIL. 1997. South Africa's offshore living marine resources: the scientific basis for management of the fisheries. Transactions of the Royal Society of South Africa 52: 149-176.

Cockcroft A, Schoeman DS, Pitcher GC, Bailey GW, van Zyl DC. 2000. A mass stranding, or 'walk out', of west coast rock lobster Jasus lalandii in Elands Bay, South Africa; causes, results and applications. In: von Kaupel Klein JC, Schram FR (eds), The biodiversity crisis and Crustacea: proceedings of the fourth international crustacean congress (vol. 2). Crustacean Issues 12: 673-688.

Cockcroft AC, van Zyl D, Hutchings L. 2008. Large-scale changes in the spatial distribution of South African West Coast rock lobsters: an overview. African Journal of Marine Science 30: 149-159.

Cockcroft VG, de Kock AC, Lord DA, Ross GJB. 1989. Organochlorines in bottlenose dolphins Tursiops truncatus from the east coast of South Africa. South African Journal of Marine Science 8: 207-217.

Coe JM, Rogers DB (eds). 1997 Marine debris: sources, impacts, and solutions. New York: Springer-Verlag.

Coetzee JC, van der Lingen CD, Hutchings L, Fairweather TP. 2008. Has the fishery contributed to a major shift in the distribution of South African sardine? ICES Journal of Marine Science 65: 1676-1688.

Crawford RJM. 2007. Food, fishing and seabirds in the Benguela upwelling system. Journal of Ornithology 148: 253-260.

Crawford RJM. 2009. A recent increase of swift terns Thalasseus bergii off South Africa - the possible influence of an altered abundance and distribution of prey. Progress in Oceanography 83: 398-403.

Crawford RJM, Altwegg R, Barham PJ, Durant JM, Dyer BM, Geldenhuys D, Makhado AB, Pichegru L, Ryan PG, Underhill LG, Upfold L, Waller LJ, Whittington PA. 2011. Collapse of South Africa's penguins in the early 21st century. African Journal of

Marine Science 33: 139-156.

Crawford RJM, Cockcroft AC, Dyer BM, Upfold L. 2008b. Divergent trends in bank cormorants Phalacrocorax neglectus breeding in South Africa' $\mathrm{s}$ Western Cape consistent with a distributional shift of rock lobsters Jasus lalandii. African Journal of Marine Science 30: 161-166.

Crawford RJM, Dundee BL, Dyer BM, Klages NTW, Meÿer MA, Upfold L. 2007 a. Trends in numbers of Cape gannets (Morus capensis), 1956/1957-2005/2006, with a 
consideration of the influence of food and other factors. ICES Journal of Marine Science 64: 169-177.

Crawford RJM, Dyer BM. 1995. Responses by four seabird species to a fluctuating availability of Cape anchovy Engraulis capensis off South Africa. Ibis 137: 329-339.

Crawford RJM, Dyer BM, Kemper J, Simmons RE, Upfold L. 2007b. Trends in numbers of Cape Cormorants (Phalacrocorax capensis) over a 50-year period, 1956-57 to 200607. Emu 107: 253-261.

Crawford RJM, Sabarros PS, Fairweather TP, Underhill LG, Wolfaardt AC. 2008d. Implications for seabirds off South Africa of a long-term change in the distribution of sardine. African Journal of Marine Science 30: 177-184.

Crawford RJM, Tree AJ, Whittington PA, Visagie J, Upfold L, Roxburg KJ, Martin AP, Dyer BM. 2008a. Recent distributional changes of seabirds in South Africa: is climate having an impact? African Journal of Marine Science 30: 189-193.

Crawford RJM, Underhill LG, Coetzee JC, Fairweather TP, Shannon LJ, Wolfaardt AC. 2008c. Influences of the abundance and distribution of prey on African penguins Spheniscus demersus off western South Africa. African Journal of Marine Science 30: 167-175.

Crawford RJM, Williams AJ, Hofmeyr JH, Klages NTW, Randall RM, Cooper J, Dyer BM, Chesselet Y. 1995. Trends of African penguin Spheniscus demersus populations in the 20th century. South African Journal of Marine Science 16: 101-108.

Cury PM, Shannon LJ. 2004. Regime shifts in upwelling ecosystems: observed changes and possible mechanisms in the northern and southern Benguela. Progress in Oceanography 60: 223-243.

Cutter G, Andersson P, Codispoti L, Croot P, Francois R, Lohan M, van der Loeff MR. 2010. Sampling and sample handling protocol for GEOTRACES cruises, Version 1.o. Available at http://www. geotraces.org/science/intercalibration/222-sampling-and-samplehandling-protocols-for-geotraces-cruises [accessed 2 October 2013].

Demarcq H. 2009. Trends in primary production, sea surface temperature and wind in upwelling systems (1998-2007). Progress in Oceanography 83: 376-385.

Demarcq H, Barlow R, Hutchings L. 2007. Application of a chlorophyll index derived from satellite data to investigate the variability of phytoplankton in the Benguela ecosystem. African Journal of Marine Science 29: 271-282.

Deutsch C, Emerson S, Thompson L. 2005. Fingerprints of climate change in North Pacific oxygen. Geophysical Research Letters 32: L16604.

Diaz RJ, Rosenberg R. 2008. Spreading dead zones and consequences for marine ecosystems. Science 321: 926-929.

Distiller G, Altwegg R, Crawford RJM, Klages NTW, Barham B. 2012. Factors affecting adult survival and inter-colony movement at the three South African colonies of Cape gannet. Marine Ecology Progress Series 461: 245-255.

Doney SC, Mahowald N, Lima I, Feely RA, Mackenzie FT, Lamarque JF, Rasch PJ. 2007. Input of anthropogenic nitrogen and sulphur deposition on ocean acidification and the inorganic carbon system. Proceedings of the National Academy of Sciences of the USA 104: 14580-14585.

Dufois F, Penven P, Whittle CP, Veitch J. 2012. On the warm nearshore bias in Pathfinder monthly SST products over Eastern Boundary Upwelling Systems. Ocean Modelling 47: 113-118. 
Dulvy N K, Rogers SI, Jennings S, Stelzenmüller V, Dye SR, Skjoldal HR. 2008. Climate change and deepening of the North Sea fish assemblage: a biotic indicator of warming seas. Journal of Applied Ecology 45: 1029-1039.

Durant JM, Crawford RJM, Wolfaardt A, Agenbag JJ, Visagie J, Upfold L, Stenseth N. 2010. Influence of feeding conditions on breeding of African penguins-importance of adequate local food supplies. Marine Ecology Progress Series 420: 263-271.

Ekau W, Verheye HM. 2005. Influence of oceanographic fronts and low oxygen on the distribution of ichthyoplankton in the Benguela and southern Angola currents. African Journal of Marine Science 27: 629-639.

Elwen S, Reeb D, Thornton M, Best PB. 2009. A population estimate of Heaviside's dolphins Cephalorhynchus heavisidii in the southern end of their range. Marine Mammal Science 25: 107-124.

Fabry VJ, Seibel BA, Feely RA, Orr JC. 2008. Impacts of ocean acidification on marine fauna and ecosystem processes. ICES Journalof Marine Science 65: 414-432.

Fairweather TP, van der Lingen CD, Booth AJ, Drapeau L, van der Westhuizen JJ. 2006. Indicators of sustainable fishing for South African sardine Sardinops sagax and anchovy Engraulis encrasicolus. African Journal of Marine Science 28: 661-680.

FAO (Food and Agriculture Organization). 2006. Report of the workshop on assessing the relative importance of sea turtle mortality due to fisheries. 25-28 April 2006, Zanzibar, United Republic of Tanzania. Meeting Report No. 1 GCP/INT/919/JPN. Rome: FAO.

Feely RA, Sabine CL, Hernandez-Ayon JM, Ianson D, Hales B. 2008. Evidence for upwelling of corrosive "acidified" water onto the continental shelf. Science 320:14901492.

Fennessy ST. 1994. The impact of commercial prawn trawlers on linefish off the north coast of Natal, South Africa. South African Journal of Marine Science 14: 263-279.

Fennessy ST, Groeneveld JC. 1997. A review of the offshore trawl fishery for crustaceans on the east coast of South Africa. Fisheries Management and Ecology 4: 135-147.

Field JG, Shillington FA. 2006. Variability of the Benguela Current system. In: Robinson $\mathrm{AR}$, Brink $\mathrm{KH}$ (eds), The sea. The global coastal ocean interdisciplinary regional studies and syntheses 14(B). President and Fellows of Harvard College. pp 835-863.

Findlay KP, Best PB, Meÿer MA. 2011. Migrations of humpback whales past Cape Vidal, South Africa, and an estimate of the population increase rate (1988-2002). In: Kirkman SP, Elwen SH, Pistorius PA, Thornton M, Weir CR (eds), Conservation biology of marine mammals in the southern African subregion. African Journal of Marine Science 33: 375-392.

Flynn KJ, Blackford JC, Baird ME, Raven JA, Clark DR, Beardall J, Brownlee C, Fabian $\mathrm{H}$, Wheeler GL. 2012. Changes in $\mathrm{pH}$ at the exterior surface of plankton with ocean acidification. Nature Climate Change 2: 510-513.

Fréon P, Drapeau L, David J, Fernández Moreno A, Leslie R, Oosthuizen H, Shannon LJ, van der Lingen CD. 2005. Spatialised ecosystem indicators in the Southern Benguela. ICES Journal of Marine Science 62: 459-468.

Fulton EA, Smith ADM, Johnson CR. 2003. Effect of complexity on marine ecosystem models. Marine Ecology Progress Series 253: 1-16. 
Garratt PA, Govender A, Punt AE. 1993. Growth acceleration at sex change in the protogynous hermaphrodite Chrysoblephus puniceus (Pisces: Sparidae). South African Journal of Marine Science 13: 187-193.

Gazeau FC, Quiblier JM, Jansen J-P, Gattuso JP, Middelburg JJ, Heip CHR. 2007. Impact of elevated $\mathrm{CO}_{2}$ on shellfish calcification. Geophysical Research Letters 34: Lo7603.

George Warman Publications. 2011. Fishing industry handbook: South Africa, Namibia and Mozambique (39th edn). Cape Town: George Warman Publications.

Gibbons MJ, Barange M, Hutchings L. 1995. The zoogeography and diversity of euphausiids around southern Africa. Marine Biology 123: 257-268.

Gibbons MJ, Buecher E, Thibault-Botha D, Helm RR. 2010. Patterns in marine hydrozoan richness and biogeography around southern Africa: implications of lifehistory strategy. Journal of Biogeography 37: 606-616.

Götz A, Kerwath SE, Attwood CG, Sauer WHH. 2009a. Effects of fishing on a temperate reef community in South Africa 1: ichthyofauna. African Journal of Marine Science 31: 241-251.

Götz A, Kerwath SE, Attwood CG, Sauer WHH. 2009b. Effects of fishing on a temperate reef community in South Africa 2: benthic invertebrates and algae. African Journal of Marine Science 31: 253-262.

Grantham HS, Petersen SL, Possingham HP. 2008. Reducing bycatch in the South African pelagic longline fishery: the utility of different approaches to fisheries closures. Endangered Species Research 5: 291-299.

Gregory MA, McClurg TP, Brouckaert CJ. 2003. The mapping of industrial effluent on coastal sediments using EDX. International Journal of Environmental Analytical Chemistry 83: 65-80.

Gregory MR. 2009. Environmental implications of plastic debris in marine settingsentanglement, ingestion, smothering, hangers-on, hitch-hiking, and alien invasions. Philosophical Transactions of the Royal Society B 364: 2013-2025.

Griffiths CL, Robinson TB, Lange L, Mead A. 2010. Marine biodiversity in South Africa: an evaluation of current states of knowledge. PLoS ONE 5: e12008.

Griffiths CL, van Sittert L, Best PB, Brown AC, Clark BM, Cook PA, Crawford RJM, David JHM, Davies BR, Griffiths MH, Hutchings K, Jerardino A, Kruger N, Lamberth SJ, Leslie RW. 2004. Impacts of human activities on marine animal life in the Benguela: a historical overview. Oceanography and Marine Biology: an Annual Review 42: 303-392.

Griffiths MH. 2000. Long-term trends in catch and effort of commercial linefish off South Africa's Cape Province: snapshots of the 2oth century. South African Journal of Marine Science 22: 81-110.

Gruber N, Hauri C, Lachkar Z, Loher D, Frolicher TL, Plattner GK. 2012. Rapid progression of ocean acidification in the California Current System. Science 6091: 220223.

Hay S. 2006. Gelatinous bells may ring change in marine eco-systems. Current Biology 16: R679-R682.

Hermes JC, Reason CJC, Lutjeharms JRE. 2007. Modeling the variability of the greater Agulhas Current system. Journal of Climate 20: 3131-3146.

Heymans JJ, Shannon LJ, Jarre A. 2004. Changes in the northern Benguela ecosystem over three decades: Ecological Modelling 172: 175-195. 
Howard JAE, Jarre A, Clark AE, Moloney CL. 2007. Application of the sequential $t$-test algorithm for analysing regime shifts to the southern Benguela ecosystem. African Journal of Marine Science 29: 437-451.

Hsieh CH, Reiss CS, Hewitt RP, Sugihara G. 2008. Spatial analysis shows that fishing enhances the climatic sensitivity of marine fishes. Canadian Journal of Fisheries and Aquatic Sciences 65: 947-961.

Hsieh CH, Reiss CS, Hunter JR, Beddington JR, May RM, Sugihara G. 2006. Fishing elevates variability in the abundance of exploited species. Nature 443: 859-862.

Huggett JA, Richardson AJ, Field JG. 2007. Comparative ecology of the copepods Calanoides carinatus and Calanus agulhensis - the influence of temperature and food. African Journal of Marine Science 29: 473-490.

Huggett JA, Verheye HMS, Escribano R, Fairweather TP. 2009. Copepod biomass, size composition and production in the southern Benguela: spatio-temporal patterns of variation, and comparison with other eastern boundary upwelling systems. Progress in Oceanography 83: 197-207.

Huisamen J, Kirkman SP, Watson LH, Pistorius PA, Cockcroft VG. 2011. Re-colonisation of the Robberg Peninsula (Plettenberg Bay, South Africa) by Cape fur seal. In: Kirkman SP, Elwen SH, Pistorius PA, Thornton M, Weir CR (eds), Conservation biology of marine mammals in the southern African subregion. African Journal of Marine Science 33: 453-462.

Hutchings L, Jarre A, Lamont T, van den Berg M, Kirkman SP. 2012. St Helena Bay (southern Benguela) then and now: muted climate signams, large human impact. African Journal of Marine Science 34: 559-583.

Hutchings L, Morris T, van der Lingen CD, Lamberth SJ, Connell AD, Taljaard S, van Niekerk L. 2010. Ecosystem considerations of the KwaZulu-Natal sardine run. African Journal of Marine Science 32: 413-421.

Hutchings L, van der Lingen CD, Shannon LJ, Crawford RJM, Verheye HMS, Bartholomae $\mathrm{CH}$, van der Plas AK, Louw D, Kreiner A, Ostrowski M, Fidel Q, Barlow RG, Lamont T, Coetzee J, Shillington F, Veitch J, Currie JC, Monteiro PMS. 2009. The Benguela Current: an ecosystem of four components. Progress in Oceanography 83: 15-32.

Hutchings L, Verheye HMS, Huggett JA, Demarcq H, Cloete R, Barlow R, Louw D, da Silva A. 2006. Variability of plankton with reference to fish variability in the Benguela Current Large Marine Ecosystem - an overview. In: Shannon LV, Hempel G, Malanotte-Rizzoli P, Malanotte-Rizoli C, Moloney CL, Woods J (eds), Benguela: predicting a large marine ecosystem. Amsterdam: Elsevier. pp 111-146.

IGBP (International Geophere-Biosphere Programme). 2012. Climate-change index 2011: rising trend continues. Global Change 78: 11.

IPCC (Intergovernmental Panel on Climate Change). 2007. Climate change 2007: the physical science basis. Contribution of Working Group I to the fourth assessment report of the Intergovernmental Panel on Climate Change [edited by Solomon S, Qin D, Manning M, Chen Z, Marquis M, Averyt KB, Tignor M, Miller HL]. Cambridge: Cambridge University Press.

James NC, Cowley PD, Whiffield AK. 2007. Abundance, recruitment and residency of two sparids in an intermittently open estuary in South Africa. African Journal of Marine Science 29: 527-538. 
James NC, Whitfield AK, Cowley PD. 2008. Preliminary indications of climate-induced change in a warm-temperate South African estuarine fish community. Journal of Fish Biology 72: 1855-1863.

Japp DW, Sims P, Smale M J. 1994. A review of fish resources of the Agulhas Bank. South African Journal of Science 90: 123-134.

Jarre A, Moloney CL, Shannon LJ, Fréon P, van der Lingen CD, Verheye HMS, Hutchings L, Roux J-P, Cury PM. 2006. Developing a basis for detecting and predicting long-term ecosystem changes. In: Shannon LV, Hempel G, Malanotte Rizzoli P, Moloney CL, Woods J (eds), Benguela: predicting a large marine ecosystem. Amsterdam: Elsevier. pp 239-273.

Jarre A, Shannon LJ. 2010. Regime shifts: physical-biological interactions under climatic and anthropogenic pressures. In: Barange M, Field JG, Harris RH, Hofmann EE, Perry I, Werner F (eds), Marine ecosystems and global change. Oxford: Oxford University Press. pp 215-216.

Kerwath SE, Götz A, Attwood CG, Sauer WHH. 2008. The effect of marine protected areas on an exploited population of sex-changing temperate reef fish: an individualbased model. African Journal of Marine Science 30: 337-350.

Kirby RR, Beaugrand G. 2009. Trophic amplification of climate warming. Proceedings of the Royal Society B 276: 4095-4103.

Kirkman SP, Oosthuizen WH, Meyer MA, Kotze PGH, Roux JP, Underhill LG. 2007. Making sense of censuses and dealing with missing data: trends in pup counts of Cape fur seal Arctocephalus pusillus pusillus for the period 1972-2004. African Journal of Marine Science 29: 161-176.

Kirkman SP, Yemane D, Oosthuizen WH, Meÿer MA, Kotze PGH, Skrypzeck H, Vaz Velho F, Underhill LG. 2013. Spatio-temporal shifts of the dynamic Cape fur seal population in southern Africa, based on aerial censuses (1972-2009). Marine Mammal Science 29: 497-524.

Krock B, Pitcher GC, Ntuli J, Cembella AD. 2009. Confirmed identification of gymnodimine in oysters from the west coast of South Africa by liquid chromatography-tandem mass spectro-metry. African Journal of Marine Science 31: $113-118$.

Link JS, Yemane D, Shannon LJ, Coll M, Shin Y, Hill L, Borges MDF. 2010. Relating marine ecosystem indicators to fishing and environmental drivers: an elucidation of contrasting responses. ICES Journal of Marine Science 67: 787-795.

Lloris D, Matallanas J, Oliver P. 2005. Hakes of the world (Family Merluccidae). An annotated and illustrated catalogue of hake species known to date. FAO Species Catalogue for Fishery Purposes. No. 2. Rome: Food and Agriculture Organization.

Lloyd P, Plagányi ÉE, Weeks SJ, Magno-Canto M, Plagányi G. 2012. Ocean warming alters species abundance patterns and increases species diversity in an African subtropical reef-fish community. Fisheries Oceanography 21: 78-94.

Lombard AT, Strauss T, Harris J, Sink K, Attwood C, Hutchings L. 2004. South African National Spatial Biodiversity Assessment 2004: Technical Report. Volume 4: Marine component. Pretoria: South African National Biodiversity Institute.

Lutjeharms JRE, Cooper J, Roberts M. 200ob. Upwelling at the inshore edge of the Agulhas current. Continental Shelf Research 20: 1907-1939. 
Lutjeharms JRE, Durgadoo JV, Schapira M, McQuaid CD. 2010. First oceanographic survey of the entire continental shelf adjacent to the northern Agulhas Current. South African Journal of Science 106: 7-9.

Lutjeharms JRE, Grundlingh ML, Carter RA. 1989. Topographically induced upwelling in the Natal Bight. South African Journal of Science 85: 310-316.

Lutjeharms JRE, Valentine HR, Van Ballegooyen RC. 2000a. The hydrography and water masses of the Natal Bight, South Africa. Continental Shelf Research 20: 1907-1939.

Mackinson S, Daskalov G, Heymans JJ, Neira S, Arancibia H, Zetina-Rejón M, Jiang H, Cheng HQ, Coll M, Arreguin-Sanchez F, Keeble K, Shannon L. 2009. Which forcing factors fit? Using ecosystem models to investigate the relative influence of fishing and changes in primary productivity on the dynamics of marine ecosystems. Ecological Modelling 220: 2972-2987.

Mann BQ (ed.). 2000. Southern African marine linefish status reports. Oceanographic Research Institute Special Publication 7. Mann BQ, Celliers L, Fennessy ST, Bailey S, Wood AD. 2006. Towards the declaration of a large marine protected area: a subtidal ichthyofaunal survey of the Pondoland coast in the Eastern Cape, South Africa. African Journal of Marine Science 28: 535-551.

Marshall DM, Rajkumar A. 2003. Imposex in the indigenous Nassarius kraussianus (Mollusca: Neogastropoda) from South African harbours. Marine Pollution Bulletin 46: 1150-1155.

Mato Y, Isobe T, Takada H, Kanehiro H, Ohtake C, Kaminuma T. 2001. Plastic resin pellets as a transport medium for toxic chemicals in the marine environment. Environmental Science \& Technology 35: 318-324.

Mead A, Griffiths CL, Branch GM, McQuaid CD, Blamey LK, Bolton JJ, Anderson RJ, Dufois F, Rouault M, Froneman PW, Whitfield AK, Harris LR, Nel R, Pillay D, Adams JB. 2013. Human-mediated drivers of change - impacts on coastal ecosystems and marine biota of South Africa. African Journal of Marine Science 35: 403-425.

Meyer AA, Lutjeharms JRE, de Villiers S. 2002. The nutrient characteristics of the Natal Bight, South Africa. Journal of Marine Science 35: 11-37.

Meÿer MA, Best PB, Anderson-Reade MD, Cliff G, Dudley SFJ, Kirkman SP. 2011. Trends and interventions in large whale entanglement along the South African coast. African Journal of Marine Science 33: 429-440.

Midgley J. 2012. Sandpiper Project. Proposed recovery of phosphate enriched sediments from the marine mining license area No. 170 off Walvis Bay Namibia. Environmental impact assessment for the marine component. Available at http://www.envirod.com/ pdf/Chapters/Chapter\%200\%20-\%20Cover\%20Summary.pdf [accessed 2 October 2013].

Moloney CL, Jarre A, Kimura S, Mackas DL, Maury O, Murphy EJ, Peterson WT, Runge JA, Tadokoro K. 2010. Dynamics of marine ecosystems: ecological processes. In: Barange M, Field JG, Harris RH, Hofmann EE, Perry I, Werner F (eds), Marine ecosystems and global change. Oxford: Oxford University Press. pp 179-218.

Moloney CL, Shillington FA. 2007. Progress towards marine ecosystem observing systems in South Africa. South African Journal of Science 103: 301-305.

Moloney CL, St John MA, Denman KL, Karl DM, Koster FW, Sundby S, Wilson RP. 2011. Weaving marine food webs from end to end under global change. Journal of Marine Systems 84: 106-116. 
Monteiro PMS, van der Plas AK. 2006. Low Oxygen Water (LOW) variability in the Benguela system: key processes and forcing scales relevant to forecasting. In: Shannon LV, Hempel G, Malanotte Rizzoli P, Moloney CL, Woods J (eds), Benguela: predicting a large marine ecosystem. Amsterdam: Elsevier. pp 71-90.

Ogata Y, Takada H, Mizukawa K, Hirai H, Iwasa S, Endo S, Mato Y, Saha M, Okuda K, Nakashima A, Murakami M, Zurcher N, Booyatumanondo R, Pauzi M, Quang L, Gordon M, Miguez C, Suzuki S, Moore C, Karapanagioti HK, Weerts S, Mcclurg T, Burres E, Smith W, Velkenburg MV, Selby J, Lang RC, Laursen D, Danner B, Stewardson N, Thompson RC. 2009. International Pellet Watch: global monitoring of persistent organic pollutants (POPs) in coastal waters. 1. Initial phase data on PCBs, DDTs, and HCHs. Marine Pollution Bulletin 58: 1437-1446.

Orr JC, Fabry VJ, Aumont O, Bopp L, Doney SC, Feely RA, Gnanadesikan A, Gruber N, Ishida A, Joos F, Key RM, Lindsay K, Maier-Reimer E, Matear R, Monfray P, Mouchet A, Najjar RG, Platter G-K, Rodgers KB, Sabine CL, Sarmiento JL, Schlitzer R, Slater RD, Totterdell IJ, Weirig M, Yamanaka Y, Yool A. 2005. Anthropogenic ocean acidification over the twenty-first century and its impact on calcifying organisms. Nature 437: 681-686.

Osman W. 2010. Trophic model-generated indicators of the southern Benguela ecosystem for communicating with fisheries managers. MSc thesis, University of Cape Town, South Africa.

Ovechkina MN, Bylinskaya ME, Uken R. 2010. Planktonic foraminiferal assemblage in surface sediments from the Thukela Shelf, South Africa. African Invertebrates 51: 231254.

Parmesan C. 2006. Ecological and evolutionary responses to recent climate change. Annual Review of Ecology Evolution and Systematics 37: 637-671.

Parmesan C. 2007. Influences of species, latitudes and methodologies on estimates of phenological response to global warming. Global Change Biology 13: 1860-1872.

Pavlakis P, Tarchi D, Sieber AJ. 2001. On the monitoring of illicit vessel discharges using spaceborne SAR remote sensing - a reconnaissance study in the Mediterranean sea. Annals of Telecommunications: 700-718.

Peña MA, Katsev S, Oguz T, Gilbert D. 2010. Modeling dissolved oxygen dynamics and hypoxia. Biogeosciences 7: 933-957.

Penney AJ, Buxton CD, Garratt PA, Smale MJ. 1997. The commercial marine linefishery. In: Payne AIL, Crawford RJM (eds), Oceans of life off southern Africa. Cape Town: Vlaeberg. pp 214-229.

Penney AJ, Mann-Lang J, van der Elst R, Wilke C. 1999. Long-term trends in catch and effort in the KwaZulu-Natal nearshore linefisheries. South African Journal of Marine Science 21: 51-76.

Penry GS, Cockcroft V, Hammond P. 2011. Seasonal fluctuations in occurrence of inshore Bryde's whales in Plettenberg Bay, South Africa, with notes on feeding and multispecies associations. African Journal of Marine Science 33: 403-414.

Penven P, Roy C, Colin de Verdiére A, Largier J. 2000. Simulation of a coastal jet retention process using a barotropic model. Oceanologica 23: 615-634.

Perry AL, Low PJ, Ellis JR, Reynolds JD. 2005. Climate change and distribution shifts in marine fishes. Science 308: 1912-1915. 
Perry RI, Cury PM, Brander K, Jennings S, Möllmann C, Planque B. 2010. Sensitivity of marine systems to climate and fishing: Concepts, issues and management responses. Journal of Marine Systems 79: 427-435.

Petersen SL, Honig MB, Ryan PG, Underhill LG. 2009. Seabird bycatch in the pelagic longline fishery off southern Africa. African Journal of Marine Science 31: 191-204.

Pichegru L, Ryan PG, Crawford RJM, van der Lingen CD, Grémillet D. 2010. Behavioural inertia places a top marine predator at risk from environmental change in the Benguela upwelling system. Marine Biology 157: 537-544.

Pitcher GC, Calder D. 2000. Harmful algal blooms of the southern Benguela Current: a review and appraisal of monitoring from 1989 to 1997. South African Journal of Marine Science 22: 255-271.

Planque B, Fromentin J-M, Cury P, Drinkwater KF, Jennings S, Perry RI, Kifani S. 2010. How does fishing alter marine populations and ecosystems sensitivity to climate? Journal of Marine Systems 79: 403-417.

Punt AE, Butterworth DS. 1995. The effects of future consumption by the Cape fur seal on catches and catch rates of the Cape hakes. 4. Modelling the biological interaction between Cape fur seals Arctocephalus pusillus pusillus and the Cape hakes Merluccius capensis and M. paradoxus. South African Journal of Marine Science 16: 255-285.

Rademeyer RA, Butterworth DS, Plagányi ÉE. 2008. Assessment of the South African hake resource taking its two-species nature into account. African Journal of Marine Science 30: 263-290.

Randall RJM. 1995. Jackass penguins. In: Payne AIL, Crawford RJM (eds), Oceans of life off southern Africa. Cape Town: Vlaeberg. pp 244-256.

Rhodes L, Selwood A, McNabb P, Briggs L, Adamson J, van Ginkel R, Laczka O. 2006. Trace metal effects on the production of biotoxins by microalgae. African Journal of Marine Science 28: 393-397.

Richardson AJ, Verheye HMS, Mitchell-Innes BA, Fowler JL, Field JG. 2003. Seasonal and event-scale variation in growth of Calanus agulhensis (Copepoda) in the Benguela upwelling system and implications for spawning of sardine Sardinops sagax. Marine Ecology Progress Series 254: 239-251.

Richardson AJ, Walne AW, John AWG, Jonas TD, Lindley JA, Sims DW, Stevens D, Witt M. 2006. Using continuous plankton recorder data. Progress in Oceanography 68: 27-74.

Roel BA. 1987. Demersal communities off the west coast of South Africa. In: Payne AIL, Gulland JA, Brink KH (eds), The Benguela and comparable ecosystems. South African Journal of Marine Science 5: 575-584.

Rogers J, Li XC. 2002. Environmental impact of diamond mining on continental shelf sediments off southern Namibia. Quaternary International 92: 101-112.

Rouault M, Pohl B, Penven P. 2010. Coastal oceanic climate change and variability from 1982 to 2009 around South Africa. African Journal of Marine Science 32: 237246.

Roux J, Shannon LJ. 2004. Ecosystem approach to fisheries management in the northern Benguela: the Namibian experience. African Journal of Marine Science 26: 79-93.

Roy C, van der Lingen CD, Coetzee JC, Lutjeharms JRE. 2007. Abrupt environmental shift associated with changes in the distribution of Cape anchovy Engraulis encrasicolus spawners in the southern Benguela. African Journal of Marine Science 29: 309-319. 
Ryan PG, Bouwman H, Moloney CL, Yuyama M, Takada H. 2012. Long-term decreases in persistent organic pollutants in South African coastal waters detected from beached polyethylene pellets. Marine Pollution Bulletin 64: 2756-2760.

Ryan PG, Moloney CL. 1990. Plastic and other artefacts on South African beaches: temporal trends in abundance and composition. South African Journal of Science 86: 450-452.

Ryan PG, Moore CJ, van Franeker JA, Moloney CL. 2009. Monitoring the abundance of plastic debris in the marine environment. Philosophical Transactions of the Royal Society B 364: 1999-2012.

Ryan PG, Swanepoel D. 1996. Cleaning beaches: sweeping the rubbish under the carpet. South African Journal of Science 92: 275-276.

Samaai T, Gibbons MJ, Kerwath S, Yemane D, Sink K. 2010. Sponge richness along a bathymetric gradient within the iSimangaliso Wetland Park, South Africa. Marine Biodiversity 40: 205-217.

SANCOR (South African Network for Coastal and Oceanic Research). 2006. Society, Ecosystems and Change (SEAChange) Programme description. Available at http://sancor.nrf.ac.za/ SitePages/SEAChange\%2oProgramme.aspx [accessed 13 August 2013].

Santana-Casiano JM, Gonzalez-Davila M, Ucha IR. 2009. Carbon dioxide fluxes in the Benguela upwelling system during winter and spring: a comparison between 2005 and 2006. Deep-Sea Research Part II 56: 533-541.

Sarmiento JL, Hughes TMC, Stouffer RJ, Manabe S. 1998. Simulated response of the ocean carbon cycle to anthropogenic climate warming. Nature 393: 245-249.

Schumann EH, Perrins L-A, Hunter IT. 1982. Upwelling along the South Coast of the Cape Province, South Africa. South African Journal of Science 78: 238-242.

Shannon LJ, Christensen V, Walters CJ. 2004. Modelling stock dynamics in the southern Benguela ecosystem for the period 1978-2002. In: Shannon LJ, Cochrane KL, Pillar SC (eds), Ecosystem approaches to fisheries in the southern Benguela. African Journal of Marine Science 26: 179-196.

Shannon LJ, Coll M, Neira S. 2009. Exploring the dynamics of ecological indicators using food web models fitted to time series of abundance and catch data. Ecological Indicators 9: 1078-1095.

Shannon LJ, Cury PM, Jarre A. 2000. Modelling effects of fishing in the Southern Benguela ecosystem. ICES Journal of Marine Science 57: 720-722.

Shannon LJ, Moloney CL, Jarre A, Field JG. 2003. Trophic flows in the southern Benguela during the 1980s and 1990s. Journal of Marine Systems 39: 83-116.

Shaughnessy PD. 1984. Historical population levels of seals and seabirds on islands off southern Africa with special reference to Seal Island, False Bay. Investigational Report of the Sea Fisheries Research Institute, South Africa 127.

Sheridan JA, Bickford D. 2011. Shrinking body size as an ecological response to climate change. Nature Climate Change 1: 401-406. Smith MD, Jarre A. 2011. Modelling regime shifts in the southern Benguela: a frame-based approach. African Journal of Marine Science 33: 17-35.

Spicer JI, Raffo A, Widdicombe S. 2007. Influence of $\mathrm{CO}_{2}$-related seawater acidification on extracellular acid-base balance in the velvet swimming crab, Necora puber. Marine Biology 151: 1117-1125. 
Stramma L, Schmidt S, Levin LA, Johnson GC. 2010. Ocean oxygen minima expansions and their biological impacts. Deep Sea Research Part I 57: 587-595.

Sunday JM, Bates AE, Dulvy NK. 2011. Global analysis of thermal tolerance and latitude in ectotherms. Proceedings of the Royal Society B 278: 1823-1830.

Turpie JK, Beckley LE, Katua SM. 2000. Biogeography and the selection of priority areas for conservation of South African coastal fishes. Biological Conservation 92: 5972.

Turpie JK, Lamberth SJ. 2010. Characteristics and value of the Thukela Banks crustacean and linefish fisheries and the potential impacts of changes in river flow. African Journal of Marine Science 32: 613-624.

Ukwe CN, Ibe CA. 2010. A regional collaborative approach in transboundary pollution management in the Guinea Current region of Western Africa. Journal of Ocean and Coastal Management 53: 493-506.

Underhill LG, Crawford RJM. 2005. Indexing the health of the environment for breeding seabirds in the Benguela ecosystem. ICES Journal of Marine Science 62: 360365.

Underhill LG, Crawford RJM, Wolfaardt AC, Whittington PA, Dyer BM, Leshoro TM, Ruthenberg M, Upfold L, Visagie J. 2006. Regionally coherent trends in colonies of African penguins Spheniscus demersus in the Western Cape, South Africa, 1987-2005. African Journal of Marine Science 28: 697-704.

van der Lingen CD, Coetzee JC, Hutchings L. 2002. Temporal shifts in the spatial distribution of anchovy spawners and their eggs in the Southern Benguela: Implications for recruitment. GLOBEC Report 16: 46-48.

van der Lingen CD, Hutchings L, Brundrit G, Byrne DA, Duncombe Rae CM, Durholtz DM, Hunter I, Lutjeharms JRE, Shannon LV, Staegemann LA. 2006b. Report of the BCLME Southern Boundary Workshop. 2-5 May 2006, Cape Town, South Africa. Unpublished report. Available at www.dlist-benguela.org [accessed October 2013].

van der Lingen CD, Shannon LJ, Cury PM, Kreiner A, Moloney CL, Roux J, Vaz-Velho F. 2006a. Resource and ecosystem variability, including regime shifts in the Benguela Current system. In: Shannon LV, Hempel G, Malanotte Rizzoli P, Moloney CL, Woods J (eds), Benguela: predicting a large marine ecosystem. Amsterdam: Elsevier. pp 147185 .

van Jaarsveld AS, Chown SL. 2001. Climate change and its impacts in South Africa. Trends in Ecology and Evolution 16: 13-14.

Verheye HMS. 2000. Decadal-scale trends across several marine trophic levels in the southern Benguela upwelling system off South Africa. Ambio 29: 30-34.

Verheye HMS, Hutchings L, Huggett JA, Carter RA, Peterson W, Painting SJ. 1994. Community structure, distribution and trophic ecology of zooplankton on the Agulhas Bank with special reference to copepods. South African Journal of Science 90: 154165.

Verheye HM[S], Richardson AJ, Hutchings L, Marska G, Gianakouros D. 1998. Longterm trends in the abundance and community structure of coastal zooplankton in the southern Benguela system, 1951-1996. In: Pillar SC, Payne AIL, Shillington FA (eds), Benguela dynamics: impact of variability on shelf-sea environments and their living resources. South African Journal of Marine Science 19: 317-332. 
Wallace JH, Kok HM, Buxton CD, Bennett B. 1984 Inshore small-mesh trawling survey of the Cape south coast. Part 1. Introduction, methods, stations and catches. South African Journal of Zoology 19: 154-164.

Walmsley SA, Leslie RW, Sauer WHH. 2007. Managing South Africa's trawl bycatch. ICES Journal of Marine Science 64: 405-412.

Watermeyer KE, Shannon LJ, Griffiths CL. 2008. Changes in the trophic structure of the southern Benguela before and after the onset of industrial fishing. African Journal of Marine Science 30: 351-382.

Watkins BP, Petersen SL, Ryan PG. 2008. Interactions between seabirds and deepwater hake trawl gear: an assessment of impacts in South African waters. Animal Conservation 11: 247-254.

Weeks S J, Currie B, Bakun A. 2002. Satellite imaging - massive emissions of toxic gas in the Atlantic. Nature 415: 493-494.

Wessels G. 2009. Meristic and morphometric variation among sardine Sardinops sagax around the coast of southern Africa. MSc thesis, University of Cape Town, South Africa.

Wilhelm M. 2012. Growth and otolith zone formation of Namibian hake Merluccius capensis. PhD thesis, University of Cape Town, South Africa.

Wolfaardt AC, Underhill LG, Altwegg R, Visagie J. 2008a. Restoration of African penguins Spheniscus demersus a decade after the Apollo Sea oil spill. African Journal of Marine Science 30: 421-436.

Wolfaardt AC, Underhill LG, Nel DC, Williams AJ, Visagie J. 2008b. Breeding success of African penguins Spheniscus demersus at Dassen Island, especially after oiling following the Apollo Sea spill. African Journal of Marine Science 30: 565-580.

Wolfaardt AC, Williams AJ, Underhill LG, Crawford RJM, Whittington PA. 2009. Review of the rescue, rehabilitation and restoration of oiled seabirds in South Africa, especially African penguins Spheniscus demersus and Cape gannets Morus capensis, 1983-2005. African Journal of Marine Science 31: 31-54.

Worm B, Hilborn R, Baum JK, Branch TA, Collie JS, Costello C, Fogarty MJ, Fulton EA, Hutchings JA, Jennings S, Jensen OP, Lotze HK, Mace PM, McClanahan TR, Minto C, Palumbi SR, Parma AM, Ricard D, Rosenberg AA, Watson R, Zeller D. 2009. Rebuilding global fisheries. Science 325: 578-585.

Yemane D, Field JG, Griffiths MH. 2004. Effects of fishing on the size and dominance structure of linefish of the Cape region, South Africa. African Journal of Marine Science 26: 161-177.

Yemane D, Field JG, Leslie RW. 2005. Exploring the effects of fishing on fish assemblages using Abundance Biomass Comparison (ABC) curves. ICES Journal of Marine Science 62: 374-379.

Yemane D, Field JG, Leslie RW. 2008. Indicators of change in the size structure of fish communities: a case study from the south coast of South Africa. Fisheries Research 93: $163-172$.

Yemane D, Field JG, Leslie RW. 2010. Spatio-temporal patterns in the diversity of demersal fish communities off the south coast of South Africa. Marine Biology: 269-281. Young IR, Zieger S, Babanin AV. 2011. Global trends in wind speed and wave height. Science 332: 451-455.

Zhang J, Gilbert D, Gooday AJ, Levin L, Naqvi SWA, Middelburg JJ, Scranton M, Ekau W, Pena A, Dewitte B, Oguz T, Monteiro PMS, Urban E, Rabalais NN, Ittekkot V, 
Kemp WM, Ulloa O, Elmgren R, Escobar-Briones E, van der Plas AK. 2010. Natural and human-induced hypoxia and consequences for coastal areas: synthesis and future development. Biogeosciences 7: 1443-1467. 